\title{
AMNESTY AND SECTION THREE OF THE FOURTEENTH AMENDMENT
}

\section{Gerard N. Magliocca*}

No Person shall be a Senator or Representative in Congress, or elector of President and Vice President, or hold any office, civil or military, under the United States, or under any State, who, having previously taken an oath, as a member of Congress, or as an officer of the United States, or as a member of any State legislature, or as an executive or judicial officer of any State, to support the Constitution of the United States, shall have engaged in insurrection or rebellion against the same, or given aid or comfort to the enemies thereof. But Congress may by a vote of two-thirds of each House, remove such disability.

Section Three of the Fourteenth Amendment ${ }^{1}$

Until January 6, 2021, Section Three of the Fourteenth Amendment was one of the vestigial portions of the Constitution. ${ }^{2}$ Designed to exclude many former Confederate officials and soldiers from federal or state office, Section Three was quickly neutered by Congress. ${ }^{3}$ In 1872 , more than the required two-thirds of the Senate and the House of Representatives passed an Amnesty Act removing disabilities from all of the former state

* Samuel R. Rosen Professor, Indiana University Robert H. McKinney School of Law. Thanks to Carlo Andreani, Garrett Epps, Mark Graber, Jill Hasday, Brian Kalt, Kurt Lash, and Myles Lynch for their comments on the draft.

1. U.S. CONST. amend. XIV, $\S 3$.

2. By vestigial, I mean a constitutional provision that is operative but written for a specific purpose that no longer seemed relevant. For a more comprehensive discussion of this subject, see Peter Beck, The Parts We Skip: A Taxonomy of Constitutional Irrelevancy, 34 CONST. COMMENT. 223 (2019).

The violence at the Capitol on January 6, 2021, occurred after this Article was drafted and shared on SSRN. To keep the Article free from any bias or appearance of bias flowing from those events, I made no textual changes to the draft on points that could be relevant to the application of Section Three to the Capitol riot. I did add some citations to those points but did so very cautiously. In a future paper, I plan to discuss fully the Section Three issues raised by the violence at the Capitol.

3. For some contemporary background on Section Three and its application by Congress, see James G. Blaine, Twenty Years of Congress: From LinColn to GARFIELD 511-15 (Norwich, Conn., Henry Bill Publ'g Co. 1886). 
officers covered by Section Three. ${ }^{4}$ Then in 1898, comparable supermajorities in Congress removed the few remaining disabilities as a gesture of national unity during the SpanishAmerican War. ${ }^{5}$ After that Section Three was almost completely forgotten, except for posthumous disability removals given to Robert E. Lee and Jefferson Davis in the 1970s. ${ }^{6}$

This Article provides the first detailed account of Section Three and argues that the provision's application was a microcosm for the arc of the Fourteenth Amendment during Reconstruction. Section Three began as a broad restructuring of state government that was given effect before the Fourteenth Amendment was even ratified by supplying the standard for disenfranchising ex-Confederates in elections for their state ratifying conventions. ${ }^{7}$ Section Three was then the first part of the Fourteenth Amendment construed by the courts. Jefferson Davis contended in 1868 that Section Three was self-executing and barred his treason prosecution, and Chief Justice Salmon P. Chase agreed with those arguments as a circuit judge presiding over the proceedings in Virginia. ${ }^{8}$ But shortly thereafter, the Chief Justice issued the first opinion on Section Three and held that the text was not self-executing in Virginia and-in the absence of congressional action - did not apply to a Black criminal defendant there. ${ }^{9}$ Following these inconsistent rulings, Congress enacted a

4. See Act of May 22, 1872, ch. 193, 17 Stat. 142 (1872) ("[A]ll political disabilities imposed by the third section of the fourteenth article of amendments of the Constitution of the United States are hereby removed from all persons whomsoever, except Senators and Representatives of the thirty-sixth and thirty-seventh Congresses, officers in the judicial, military, and naval service of the United States, heads of departments, and foreign ministers of the United States.").

5. See Act of June 6,1898 , ch. 389,30 Stat. 432 ("[T] he disability imposed by section three of the Fourteenth Amendment to the Constitution of the United States heretofore incurred is hereby removed.").

6. See S.J. Res. 23, 94th Cong. (1975) (Robert E. Lee); S.J. Res. 16, 95th Cong. (1978) (Jefferson Davis); Robert PENN WARREN, JEFFERSON DAVIS GeTS HIS CITIZENSHIP BACK 93-94 (1980). The only other application of Section Three was to Representative Victor Berger, a member of the House of Representatives who was excluded from office after criticizing American involvement in World War I. See 6 Clarence CANNON, CANNON's PRECEDENTS OF THE HOUSE OF REPRESENTATIVES OF THE UNITED STATES 52-63 (1936); JOSH ChAFETZ, DEMOCRACY'S PRIVILEGED FEW 189-91 (2007). Berger's case is a quirky example that predates modern First Amendment doctrine and is not addressed in this Article.

7. See First Military Reconstruction Act, ch. 153, § 5, 14 Stat. 428, 428-30 (1867).

8. See Case of Davis, 7 F. Cas. 63, 90, 92-94, (C.C.D. Va. 1867) (No. 3,621a) (describing Davis's argument and the Government's response); id. at 102 (noting the Chief Justice's view).

9. See Griffin's Case, 11 F. Cas. 7, 26 (C.C.D. Va. 1869) (No. 5,815). 
Section Three enforcement statute and federal prosecutors brought many actions to oust ineligible officials, including half of the Tennessee Supreme Court. ${ }^{10}$ The reforming zeal of Reconstruction was at its peak.

By 1871, though, political pressure for sectional reconciliation led President Ulysses S. Grant to ask Congress to remove the Section Three disabilities. ${ }^{11}$ Senator Charles Sumner then led an unsuccessful effort to forge a grand bargain under which Section Three relief would be combined with a new civil rights measure that would, among other things, bar racial segregation in public schools. ${ }^{12}$ The failure of that compromise, along with Congress's decision to grant a freestanding Section Three amnesty, was a harbinger of Reconstruction's doom and the contraction of the Fourteenth Amendment in the Supreme Court. ${ }^{13}$ The amnesty debate also raised deep questions about the meaning of representation, the way in which divided societies should be reunited, and whether the Fourteenth Amendment was mainly concerned with legal neutrality or ending white supremacy. These questions haunt us still.

Part I reviews the text of Section Three and what we know of its original public meaning during the proposal and ratification stages. Part II explores how Section Three was enforced against southern officeholders, with a special focus on Chief Justice Chase's analysis in Griffin's Case - the first major Fourteenth Amendment opinion - as compared to his view of Section Three

10. See Act of May 31, 1870 (First Ku Klux Klan Act), ch. 114, § 14, 16 Stat. 140, 143; $i d$. at $\S 15$ (imposing criminal penalties for knowing Section Three violations) [hereinafter First Ku Klux Klan Act]; Sam D. Elliott, When the United States Attorney Sued to Remove Half the Tennessee Supreme Court: The Quo Warranto Cases of 1870, 49 TENN B.J. 20 (2013).

11. See Ulysses S. Grant, Third Annual Message (Dec. 4, 1871), in 9 A COMPILATION of the Messages AND PAPERS OF THE PRESIDENTS 4096, 4107 (James D. Richardson ed., New York, Bureau of Nat'l Literature, Inc. 1897); see also 1 NATIONAL PARTY PlATFORMS 44 (Donald Bruce Johnson ed., 1978) (quoting the Liberal Republican Platform of 1872, which called for Section Three amnesty).

12. See David Herbert Donald, Charles Sumner and the Rights of MaN 534-39 (1970); Michael W. McConnell, Originalism and the Desegregation Decisions, 81 VA. L. REV.947, 1049-60 (1995). Parts of the Sumner amendment were enacted as the Civil Rights Act of 1875. See The Civil Rights Cases, 109 U.S. 3 (1883) (invalidating most of the 1875 Civil Rights Act).

13. See, e.g., Slaughter-House Cases, 83 U.S. (16 Wall.) 36 (1873); see also RoN CHERNOW, GRANT 843-49 (2017) (describing the disputed presidential election of 1876 and the pledge by President-Elect Hayes to withdraw federal troops from the South in exchange for the White House). 
in Jefferson Davis's treason case. ${ }^{14}$ Part III takes a close look at the congressional debate on amnesty from 1871-1872. Part IV concludes by discussing Section Three's gradual and ironic deletion from history.

\section{PART I. PROPOSAL AND RATIFICATION}

This Part parses the text of Section Three and examines its public understanding until the Fourteenth Amendment was ratified. From a modern vantage point, the most intriguing facet of Section Three was its implicit endorsement of the view that a small clique of enslavers-the so-called Slave Power-bore primary responsibility for the Civil War and thus should be purged from office. ${ }^{15}$ The most important contemporary issue for Section Three, however, was about whether the provision was best read as a new qualification for office or as a punishment, which became an issue in the Jefferson Davis treason case. ${ }^{16}$ All of these points are illuminated by the unusual fact that Section Three is the only constitutional provision that was enforced prior to its ratification. ${ }^{17}$

14. 11 F. Cas. 7, 22-27 (C.C.D. Va. 1869) (No. 5,815). The case is sometimes referred to as In Re Griffin, but this Article uses the alternative name Griffin's Case.

15. See, e.g., ERIC FONER, THE SECOND Founding: How THE CIVIL WAR AND RECONSTRUCTION REMADE THE CONSTITUTION 84 (2019); GARRETT EPPS, DEMOCRACY REBORN: THE FOURTEENTH AMENDMENT AND THE FIGHT FOR EQUAL RIGHTS IN POST-CIVIL WAR AMERICA 73 (2006) (referring to "the white planters, politicians, and merchants who had made up the Slave Power" before the Civil War). Mark Graber is working on a book about Sections Two, Three, and Four of the Fourteenth Amendment. I am grateful for his research on Section Three, some of which he shared with me. This Article spends most of its time on what occurred after Section Three was proposed by Congress rather than on what was discussed there in 1866.

16. See, e.g., Richard M. Re \& Christopher M. Re, Voting and Vice: Criminal Disenfranchisement and the Reconstruction Amendments, 121 YALE L.J. 1584, 1616-24 (2012); see also Case of Davis, 7 F. Cas. 63, 89-102 (C.C.D. Va. 1867); CARLTON F. W. LARSON, ON TREASON: A CitIZEN's GUIDE TO THE LAW 127-28 (2020); CYNTHIA Nicoletti, SECESSION ON TRIAL: The TREASON PROSECUTION OF JEFFERSON DAVIS 294-99 (2017); C. Ellen Connally, The Use of the Fourteenth Amendment by Salmon P. Chase in the Trial of Jefferson Davis, 42 AKRON L. REV. 1165 (2009); Dwight J. Davis, The Legal Travails of Jefferson Davis: A Review and Lessons Learned, 23 J. S. LEGAL HIST. 27, 73-76 (2015).

17. Granted, this is an arguable proposition that depends on calling a delegate to a state constitutional convention a state officer. See infra text accompanying notes 53-54. But no other constitutional provision was directly referenced and applied by a statute prior to that provision's ratification, which itself makes Section Three special. 


\section{A. The Problem of AleXander Stephens}

When the Thirty-Ninth Congress convened in December 1865, Senators and elected Representatives from the exConfederate States showed up ready to take their seats. Among those members-elect were many rebel leaders, including Alexander Stephens, the Confederate Vice President, two Confederate Senators, four Confederate Congressmen, and several military officers of the Confederate Army. ${ }^{18}$ The presence of these unrepentant rebels infuriated most Republicans in Congress. As the Joint Committee on Reconstruction explained in its report, the elections in the South "resulted, almost universally, in the defeat of candidates who had been true to the Union, and in the election of notorious and unpardoned rebels ... who made no secret of their hostility to the government and the people of the United States." ${ }^{19}$ The Joint Committee thus recommended "the exclusion from positions of public trust of, at least, a portion of those whose crimes have proved them to be enemies to the Union, and unworthy of public confidence." ${ }^{20}$

The ensuing language of Section Three was introduced in the Senate as a substitute to the House's proposal. ${ }^{21}$ Representative James G. Blaine, who later served as the Speaker of the House, recalled in his memoir that when the proposal "was under discussion in Congress, the total number affected was estimated at fourteen thousand, but subsequently it was ascertained to be much greater." ${ }^{22}$ In the discussion of the Senate proposal, one objection was that exclusion would make ratification of the

18. See EdWARd McPherson, The Political History of THE United States OF AMERICA DURING THE PERIOD OF RECONSTRUCTION 107-09 (Washington, Solomons \& Chapman 1875).

19. Joint COMm. On Reconstruction, 39th Cong., Report of the JoInT COMMITTEE ON RECONSTRUCTION, at x (1st Sess. 1866).

20. Id. at xviii; see 2 BLAINE, supra note 3, at 190 ("It was therefore the general expectation of the people that by some law, either statute or organic, the political privileges of these men, so far as the right to hold office was involved, should be restricted ....").

21. The initial proposal from the Joint Committee would have disenfranchised exConfederates from voting in all national elections until 1870. See Cong. GLOBE, 39th Cong., 1st Sess. 2545 (1866) ("Until the 4th day of July, in the year 1870, all persons who voluntarily adhered to the late insurrection, giving it aid and comfort, shall be excluded from the right to vote for Representatives in Congress and for electors for President and Vice-President of the United States."); FONER, supra note 15, at 84. This idea received no support in the Senate and was abandoned. See Re \& Re, supra note 16, at 1617; see also CONG. GlobE, 39th Cong., 2d Sess. 1212 (1867) (statement of Rep. Bingham) (retelling the background of the Joint Committee proposal).

22. BLAINE, supra note 3 , at 511. 
Fourteenth Amendment impossible in the South. ${ }^{23}$ Another Senator said that sidelining the old local political establishment would greatly hamper cooperation with the Union: "Do you not want to act upon the public opinion of the masses of the South? Do you not want to win them back to loyalty? And if you do, why strike at the men who, of all others, are most influential and can bring about the end which we all have at heart?" ${ }^{4}$ The Joint Committee's response to this type of claim was: "Slavery, by building up a ruling and dominant class, had produced a spirit of oligarchy adverse to republican institutions, which finally inaugurated civil war. The tendency of continuing the domination of such a class, by leaving it in the exclusive possession of political power, would be to encourage the same spirit, and lead to a similar result." 25

The Joint Committee's logic for what became Section Three evoked an abolitionist mantra that a "Slave Power" of Southern elites was to blame for the Civil War. Prior to the 1860s, many in the North believed that rich enslavers were conspiring secretly to extinguish liberty. ${ }^{26}$ Although there was a paranoid aspect to that view, there was a pragmatic reason to single out the political class once the war was over. Giving other whites a pass arguably raised the prospects for reconciliation in much the way that the Nuremberg Trials did for Germany after World War II by focusing on Nazi leaders and not on their followers. ${ }^{27}$ There was

23. See, e.g., CONG. Globe, 39th Cong., 1st Sess. 2900 (1866) (statement of Sen. Doolittle).

24. Id. at 2898-99 (1866) (statement of Sen. Johnson). Senator Johnson opposed the entire Fourteenth Amendment, so his statement about Section Three must be taken with a grain of salt.

25. JOINT COMM. ON RECONSTRUCTION, supra note 19, at xiii; see also FONER, supra note 15, at 84 (quoting a Republican Congressman who supported Section Three on the grounds that the South needed new officials with "some regard for the principles that are contained in the Declaration of Independence").

26. See GARry Wills, "NEgro PresidenT": JefFerson AND THE SlaVe POWER 9-10 (2003); Compare DAVID BRION DAVIS, THE SLAVE POWER CONSPIRACY AND THE PARANOID STYLE (1970) (examining this belief and concluding that no such conspiracy existed), with LEONARD L. Richards, THE SlAVE POWER: THE FreE NORTH AND SOUTHERN DOMINATION, 1780-1860 (2000) (challenging Davis's conclusions).

27. See, e.g., GitTa SERENy, Albert SPEER: His BATtLe With Truth 576 (1995) (quoting Robert Jackson's opening statement at Nuremberg, which said: "We would also make clear that we have no purpose to incriminate the whole German people .... The German no less than the non-German world has accounts to settle with these defendants."). The ineffectiveness of Section Three to achieve lasting political change might be analogized to the mixed results that followed similar efforts to exclude former Nazis from office in Germany, but that comparison is beyond the scope of this Article. 
also a plausible thought that the Confederate leaders were not truly representative of their voters and chose to exercise their independent judgment in a destructive manner. ${ }^{28} \mathrm{~A}$ new group of leaders, one could hope, would produce a different racial and political stance.

\section{B. COMPARING Section ThreE TO THE 1787 CONSTITUTION}

Turning to the text of Section Three, the first notable point involves its list of the federal offices subject to exclusion. Senators, Representatives, and electors for President and Vice President are specified. After that, the text refers to "any office, civil or military, under the United States." One implication of this language is that Senators, Representatives, and electors do not hold an office under the United States. The other implication is that the Presidency and the Vice-Presidency are each offices under the United States. ${ }^{29}$ During the debate on Section Three, one Senator asked why ex-Confederates "may be elected President or Vice President of the United States, and why did you omit to exclude them? I do not understand them to be excluded from the privilege of holding the two highest offices in the gift of the nation." ${ }^{30}$ Another Senator replied that the lack of specific language on the Presidency and Vice-Presidency was irrelevant: "Let me call the Senator's attention to the words 'or hold any office, civil or military, under the United States." 31 Practically speaking, Congress did not intend (nor would the public have understood) that Jefferson Davis could not be a Representative

28. Put another way, Confederate officials might have acted like Edmund Burke but not in a Burkean fashion. Cf. Edmund Burke, Speech to Electors of Bristol (Nov. 3, 1774), in 2 THE WORKS OF THE RIGHT HONORABLE EDMUND BURKE 89, 95-96 (Boston, Little, Brown, \& Co. 1871) (stating that an elected official should exercise his best judgment rather than simply follow the wishes of his constituents).

29. For a thoughtful critique of this view, see Josh Blackman \& Seth Barrett Tillman, Is the President an 'Officer of the United States' for Purposes of Section Three of the Fourteenth Amendment, VOLOKH CONSPIRACY (Jan. 20, 2021), https://reason.com/ volokh/2021/01/20/is-the-president-an-officer-of-the-united-states-for-purposes-of-section -3-of-the-fourteenth-amendment/. If there is an attempt to apply Section Three to former President Trump for his role in the events of January 6, 2021, the issue of whether Section Three applies to him or to the presidency itself will surely be part of any ensuing litigation.

30. Cong. Globe, 39th Cong., 1st Sess. 2899 (1866) (statement of Sen Johnson).

31. Id. (statement of Sen. Morrill); cf. Speech of Hon. John A. Bingham, N. H. StATESman, Aug. 24, 1866, at 1 (stating that Section Three meant broadly that "no man who broke his official oath with the nation or State, and rendered service in this rebellion shall, except by the grace of the American people, be again permitted to hold a position, either in the National or State Government."). 
or a Senator but could be President. ${ }^{32}$

Next, Section Three helped define Section Two of the Fourteenth Amendment. Section Two sets forth a complicated formula that penalizes states for disenfranchising presumptively eligible voters by reducing their representation in the House of Representatives and in the Electoral College in proportion to the disenfranchisement. ${ }^{33}$ An exception to that penalty was "for participation in rebellion, or other crime." "Rebellion" was also used in Section Three and gave more specific guidance on what the same word meant in Section Two. As we will see in a moment, some Southern states relied on Section Three in their post-bellum constitutions to decide who could be disenfranchised consistent with Section Two. ${ }^{34}$

Third, Section Three vested the authority to grant absolution in Congress rather than in the President. This is consistent with the broader structure of the Fourteenth Amendment, which focuses on the power and composition of Congress. ${ }^{35}$ Section Three is also a striking exception to the President's pardon power aside from impeachment, and reflects the bitter antagonism between Congress and President Andrew Johnson that led to the proposal of the Fourteenth Amendment in the first place. ${ }^{36}$ President Johnson issued pardons to many former Confederates in a way that upset leading members of Congress, and they were unwilling to give Johnson or any other President the ability to remove Section Three disabilities. ${ }^{37}$ At the same time, for a

32. Perhaps one could say that ex-Confederates were not expected to win the presidency or the vice-presidency, which is why Section Three did not bar them from those offices. But this is not a persuasive argument in light of the sweeping arguments by the proponents and opponents of Section Three that did not admit of exceptions for the President or Vice President.

33. See Gerard N. Magliocca, Our Unconstitutional Reapportionment Process, 86 GEO. WASH. L. REV. 774 (2018).

34. See infra text accompanying notes 55-56.

35. As just explained, Section Two discusses how Representatives should be apportioned in the House and contemplates congressional enforcement of the penalty provision. Likewise, Section Five describes Congress's enforcement power.

36. See generally David O. STEWART, ImPEACHed: The Trial of ANDreW JOHNSON AND THE FIGHT FOR LINCOLN'S LEGACY (2009) (describing the fight between the President and Congressional Republicans that culminated in impeachment); see also U.S. CONST. art. II, $\S 2$, cl. 1 (stating that the pardon power does not extend to "Cases of Impeachment").

37. See Re \& Re, supra note 16 , at 1618 . One issue raised in Congress was whether pardons already given by President Johnson to the people subjected to Section Three exempted them from the exclusion provision. See BLAINE, supra note 3, at 205-07, 209-12 (summarizing that debate). The Senate rejected an amendment creating an exception in 
legislative pardon Section Three imposed one of the few supermajority requirements in the Constitution.

Fourth, Section Three marked the first time that the Constitution placed substantive limits on a state's authority to choose its own officials. Article One gives Congress the power to exclude particular members sent as Representatives or Senators by a state. ${ }^{38}$ Article Two restricts whom state legislatures can name as presidential electors. ${ }^{39}$ Article Four provides that an entire state government can be displaced in extraordinary cases. ${ }^{40}$ But the Constitution says nothing about who can or cannot be a state official. Section Three's unprecedented intervention in state governance resonated with the nationalist spirit of the Fourteenth Amendment, expressed best by Section One but also present in Sections Two, Four, and Five. ${ }^{41}$

The final textual observation is that Section Three draws on the Treason Clause. The Treason Clause defines that crime as "levying War against [the United States], or in adhering to their Enemies, giving them Aid and Comfort." ${ }^{42}$ Section Three instead uses the phrase "given aid or comfort to the enemies thereof." The parallels between the Treason Clause and Section Three shaped the argument that the exclusion from office was a punishment that violated constitutional norms. ${ }^{43}$ One Senator

Section Three who those "who have duly received pardon and amnesty under the Constitution and laws." See id. at 211. As a result, Section Three was applied to people who had received a presidential pardon, but in 1885 the Attorney General took the view that a pardon superseded Section Three. See infra text accompanying notes 202-208.

38. See U.S. CONST. art. I, $\S 5$, cl. 1 .

39. See id. art. II, § 1, cl. 2.

40. See id. art. IV, $\S 4$ ("[T]he United States shall guarantee to every State in this Union a Republican Form of Government ...."). Indeed, this is one way of justifying what occurred during Military Reconstruction. See, e.g., AKHIL REED AMAR, AMERICA's CONSTITUTION: A BIOGRAPHY 368-80 (2005). The Guarantee Clause has not been used against a single state official or small group of state officials, though on one occasion Congress gave that issue some consideration. See Gerard N. Magliocca, Huey P. Long and the Guarantee Clause, 83 TUL. L. REV. 1 (2008).

41. Section Four of the Fourteenth Amendment provided that the validity of the national debt, especially in connection with suppressing the rebellion "shall not be questioned." U.S. CONST. amend. XIV, § 4. Section Five addressed Congress's power to enforce the rest of the Fourteenth Amendment. See id. at $\S 5$.

42. U.S. CONST. art. III, § 3, cl. 1 .

43. See, e.g., Cong. Globe, 39th Cong., 1st Sess. 2900 (1866) (statement of Sen. Doolittle) (stating that Section Three was "in the nature of a bill of pains and penalties, imposed by constitutional enactment it is true, but it is a punishment different from the punishment now prescribed by law"); $c f . i d$. at 2899 (statement of Sen. Guthrie) ("This third section is not an act of conciliation, it is an act of proscription."). One Senator compared Section Three to the disqualification of impeached and convicted officials, see 
attacked Section Three because he was against "to the infliction of punishment of any kind upon anybody unless by fair trial." ${ }^{44} \mathrm{~A}$ Congressman added that Section Three was a criminal "bill of attainder or ex post facto law." 45 And when Chief Justice Chase gave Section Three its first judicial interpretation in Griffin's Case (discussed in Part II), he said that "it can hardly be doubted that the main purpose was to inflict upon the leading and most influential characters who had been engaged in the Rebellion, exclusion from office as a punishment for the offense." 46

Section Three's supporters disagreed about whether exclusion from office was properly read as a punishment. John Bingham, the lead drafter of Section One of the Fourteenth Amendment, described Section Three to an Ohio crowd during his 1866 reelection campaign and said that the ex-rebel leaders "surely have no right to complain if this is all the punishment the American people shall see fit to impose upon them." ${ }^{47}$ Senator Lyman Trumbull, though, rejected a penal reading of Section Three: "[W]ho ever heard of such a proposition ... that a bill excluding men from office is a bill of pains and penalties and punishment?"48 Senator Trumbull stated that the Constitution "declares that no one but a native-born citizen of the United States shall be President ... Does, then, every person living in this land who does not happen to have been born within its jurisdiction undergo pains and penalties and punishment all his life, because by the Constitution he is ineligible to the Presidency?"49 This dispute remains unresolved, as the Supreme Court has never decided the proper view of Section Three..$^{50}$

id. at 2915 (statement of Sen. Doolittle), though that comparison refutes the claim that disqualification from office is a criminal punishment given that the Constitution's impeachment provisions expressly distinguish disqualification from office from any criminal penalties that might be imposed afterwards. See U.S. CONST. art. I, § 3, cl. 7.

44. See Cong. Globe, 39th Cong., 1st Sess. 2899 (1866) (statement of Sen. Cowan).

45. Id. at 2467 (1866) (statement of Rep. Boyer); see id. at 879 (statement of Sen. Hendricks) (also making an ex post facto argument). Nobody argued that Section Three was unconstitutional. Rather, the point was that retroactive punishments imposed without trial were contrary to the spirit of the 1787 Constitution. See Griffin's Case, 11 F. Cas. 7, 21 (C.C.D. Va. 1869) (No. 5,815).

46. Griffin's Case, 11 F. Cas. at 26.

47. The Constitutional Amendment: Discussed By Its Author, Cincinnati Com., Aug. 27, 1866, at 1 .

48. CONG. GlobE, 39th Cong., 1st Sess. 2901 (1866) (statement of Sen. Trumbull).

49. Id; see id. at 2918 (statement of Sen. Willey) (stating that Section Three was not "penal in its character, it is precautionary").

50. See Powell v. McCormack, 395 U.S. 486, 520 n.41 (1969) (declining to address the 


\section{Military Reconstruction and State Constitutions}

Section Three was the first part of the proposed amendment that Congress used. When the former Confederate states (save Tennessee) rejected the Fourteenth Amendment, Congress replied by creating a new process for organizing those state governments that relied, in part, on Section Three. ${ }^{51}$ The First Military Reconstruction Act directed these ten states to draft new constitutions and ordered that nearly all male adult Blacks be allowed to vote in elections for the constitutional conventions. ${ }^{52}$ But the Act stated that "no person excluded from the privilege of holding office by said proposed amendment to the Constitution of the United States, shall be eligible to election as a member of the convention to frame a constitution for any of said rebel States, nor shall any such person vote for members of such convention." 53 Congress soon enacted the Second Military Reconstruction Act, which authorized the Army to register voters for those state convention elections and required voters to swear an oath stating that they were not subject to Section Three. ${ }^{54}$ These Reconstruction Acts created an electorate that was more favorable for establishing state governments in support of ratifying the Fourteenth Amendment, including Section Three.

Section Three also appeared in four of the new state constitutions written under the auspices of the Reconstruction Acts. The South Carolina and Texas Constitutions stated: "[N]o person shall be allowed to vote or hold office who is now or hereafter may be disqualified therefor by the Constitution of the United States, until such disqualification shall be removed by the Congress of the United States." ${ }^{55}$ This clause incorporated Section

issue); see also U.S. Term Limits, Inc. v. Thornton, 514 U.S. 779, 787 n.2 (1995) (same)

51. See Gerard N. Magliocca, American Founding Son: John Bingham AND THE INVENTION OF THE FOURTEENTH AMENDMENT 124, 129-38 (2013); Gabriel J. Chin, The "Voting Rights Act of 1867": The Constitutionality of Federal Regulation of Suffrage During Reconstruction, 82 N.C. L. REV. 1581, 1590-91 (2004).

52. See First Military Reconstruction Act, ch. 153. § 5, 14 Stat. 428, 428-30 (1867) (stating that "a convention of delegates elected by the male citizens of said State, twentyone years old and upward, of whatever race, color, or previous condition" except for felons would frame the new state constitutions).

53. Id.

54. See Second Military Reconstruction Act, ch. 6, § 1, 15 Stat. 2 (1867); Re \& Re, supra note 16, at 1625 . The Third Military Reconstruction Act clarified that the denial of suffrage should be read broadly to include people who held any "civil offices created by law for the administration of any general law of a State, or for the administration of justice." See Third Military Reconstruction Act, ch. 30, § 6, 15 Stat. 14, 15 (1867).

55. S.C. CONST. of 1868, art. VIII, § 2; TEX. CONST. of 1869 , art. VI, $\$ 1$. 
Three by reference (given the language about Congress removing the disqualification) and applied to all elections. Furthermore, these states stripped themselves of authority to restore suffrage to these citizens-only Congress could do so. Alabama and Arkansas put more modest restrictions in their constitutions that pegged suffrage to Section Three but permitted the legislature to remove the disability if Congress did not act. ${ }^{56} \mathrm{~A}$ decision by Congress to grant Section Three amnesty, hence, would restore voting rights to some ex-Confederates in the South. ${ }^{57}$

When the first batch of ex-Confederate states ratified the Fourteenth Amendment and were readmitted in 1868, Congress again invoked Section Three in the legislation restoring their representation. This readmission act provided: "[N]o person prohibited from holding office under the United States, or under any State, by section three of the proposed amendment to the Constitution of the United States, known as article fourteen, shall be deemed eligible to any office in either of said States, unless relieved from disability [by Congress]." 58 This law was enacted shortly before ratification of the Fourteenth Amendment, and one state case later held that an ineligible judge's acts taken after this statute was enacted but prior to the Amendment's ratification were invalid. ${ }^{59}$ One state readmitted by this Act was Georgia, but

56. See ALA. CONST. of 1868 , art. VII, $\S 3$ (denying suffrage to "[t]hose who may be disqualified from holding office by the proposed amendment to the Constitution of the United States, known as 'Article XIV,"' but stating that "the General Assembly shall have power to remove the disabilities incurred under this clause"); ARK. CONST. of 1868, art. VIII, $\S 3$ (denying suffrage (with some exceptions) to anyone covered by Section Three of the Fourteenth Amendment and permitting the state legislature (by a two-thirds vote) and the Governor to waive the disability).

57. It is unclear how many men lost the right to vote in these states or how many of them had their rights restored by the 1872 congressional amnesty. All of these state constitutional provisions were subsequently repealed.

58. See Act of June 25,1868 , ch. $70, \S 3,15$ Stat. 73, 74. Another notable feature of this statute is its statement that "the constitutions of neither of the said States shall ever be so amended or changed to deprive any citizen or class of citizens of the United States of the right to vote in said State, who are entitled to vote by the constitution thereof herein recognized, except as a punishment for such crimes as are now felonies at common law, whereof they shall have been duly convicted under laws equally applicable to all the inhabitants of said State." Id. § 2. This provision was not enforced when Jim Crow constitutional reforms deprived Blacks of voting rights. The reference in that language to "crimes as are now felonies at common law" suggests a narrower definition of Section Two of the Fourteenth Amendment that current Supreme Court doctrine, which holds that a state may disenfranchise someone for any felony. See Richardson v. Ramirez, 418 U.S. 24 (1974).

59. See State ex rel. Sandlin v. Watkins, 21 La. Ann. 631, 633-34 (La. 1869). Other state cases about Section Three relied on the Fourteenth Amendment itself rather than on 
in 1869 Georgia was kicked out of Congress for expelling all of its Black legislators and not its white legislators who were ineligible under Section Three. ${ }^{60}$ President Grant asked Congress to take action to enforce "the third clause of the fourteenth amendment." ${ }^{61}$ Congress then directed the Governor to summon the state legislature into special session and require all members to swear that they were eligible or were "relieved, by an act of the Congress of the United States, from disability as provided for by section three of the fourteenth amendment to the Constitution of the United States." 62 Through Section Three, therefore, Congress and the Executive Branch were now deeply involved in internal state politics.

In sum, Section Three was narrow but deep. The exclusion from office embraced a theory that the political and military elites of the South were the only people who should bear constitutional responsibility for the Civil War. In making that judgment, however, Congress limited a state's ability to choose its leaders and would force some of them to clean house.

any state readmission statute. See Worthy v. Barrett, 63 N.C. 99 (1869) (holding that a county sheriff who held that office before and during the Civil War was disqualified from office under Section Three); In Re Tate, 63 N.C. 308 (1869) (holding that a state solicitor who was a county attorney before the Civil War and served in the Confederate Army was disqualified by Section Three); $c f$. Sands v. Commonwealth, 62 Va. (21 Gratt.) 871, 885-87 (1872) (rejecting a claim that the Virginia Constitution incorporated the Section Three exclusion as applied to jury service); State ex rel. Downes v. Towne, 21 La. Ann. 490 (La. 1869) (holding that state judge could not be dismissed as ineligible without a court judgment).

60. See, e.g., Ulysses S. Grant, First Annual Message (Dec. 6, 1869), in 9 MESSAGES, supra note 11, at 3981, 3982 (stating that the Georgia Legislature "unseated the colored members of the legislature and admitted to seats some members who are disqualified by the third clause of the fourteenth amendment to the Constitution-an article which they themselves had contributed to ratify").

61. See id. ("Under these circumstances I would submit to you whether it would not be wise, without delay, to enact a law authorizing the governor of Georgia to convene the members originally elected to the legislature, requiring each member to take the oath prescribed by the reconstruction acts, and none to be admitted who are ineligible under the third clause of the fourteenth amendment.").

62. See Act of Dec. 22,1869 , ch. $3, \S 2,16$ Stat. 59, 60; id. § 6 (stating that excluding legislators on the basis of race was "illegal, and revolutionary, and is hereby prohibited"); id. $\S 8$ (requiring Georgia to ratify the Fifteenth Amendment for readmission). When the Legislature refused to comply, the Union Army enforced Congress's mandate by removing the ineligible lawmakers and restoring the Black legislators in what white supremacists called "Terry's Purge." See JAMES Ford RHODES, 6 History Of THE UNITED STATES FROM THE COMPROMISE OF 1850 TO THE FINAL RESTORATION OF HOME RULE AT THE SOUTH IN 1877, at 288-89 (1912). 


\section{PART II. ENFORCEMENT}

This Part discusses Section Three's life immediately after the Fourteenth Amendment's ratification. The first man to invoke Section Three was Jefferson Davis. He argued in proceedings before Chief Justice Chase that the provision barred his treason prosecution in Virginia. ${ }^{63}$ The Chief Justice concurred with Davis's argument, but just a few months later he held in Griffin's Case that Section Three did not apply to a Black criminal defendant in Virginia without enforcement by an Act of Congress. ${ }^{64}$ These two different assessments about whether Section Three was self-executing in Virginia are almost impossible to reconcile, and the Chief Justice's logic in Griffin's Case was a harbinger of the Fourteenth Amendment's troubled future as a tool for racial fairness. Not long afterwards, Congress enacted a general enforcement law for Section Three that gave priority to civil actions seeking to oust ineligible officials and imposed criminal penalties on those who did not step down. ${ }^{65}$ This period of Section Three enforcement is not well known and was part of Congress's effort to defeat the Ku Klux Klan.

\section{A. JEFFERSON DAVIS AND CHIEF JUSTICE CHASE}

After Jefferson Davis was indicted by the United States for treason and after the Fourteenth Amendment was ratified, his lawyers argued that Section Three imposed a punishment and that this penalty barred a treason prosecution. ${ }^{66}$ The argument was suggested to Davis's defense team by none other than Chief Justice Chase, one of the two judges who presided over the pretrial motions in federal circuit court. ${ }^{67}$ Davis then took the

63. On this score, there is a parallel between Davis's case and the fact that white Southerners were the first plaintiffs to have a case decided in the Supreme Court on the meaning of Section One of the Fourteenth Amendment. See Slaughter-House Cases, 83 U.S. (16 Wall.) 36 (1873); BARRY FriedMAN, THE WiLl of THE PEOPLE: How PUbliC OPINION HAS INFLUENCED THE SUPREME COURT AND SHAPED THE MEANING OF THE CONSTITUTION 141 (2009).

64. 11 F. Cas. 7, 26 (C.C.D. Va. 1869) (No. 5,815).

65. First Ku Klux Klan Act, ch. 114, §§ 14-15, 16 Stat. 140, 143-44 (1870).

66. See Case of Davis, 7 F. Cas. 63, 89 (C.C.D. Va. 1867) (No. 3,621a). Just to be clear, these arguments were made in late 1868 even though the report lists the date as 1867 , which is when the initial indictment was issued against Davis.

There were many legal and political difficulties with trying Jefferson Davis for treason that went beyond Section Three. For excellent discussions of the wider context, see LARSON, supra note 16, at 122-26; NICOLETTI, supra note 16, at 5-10.

67. See Davis, supra note 16, at 73-74; NICOLETTI, supra note 16, at 294-96. In this era, each Justice rode circuit and sat with a federal district judge to hear appeals and to 
position that Congress intended Section Three as an exclusive criminal punishment. ${ }^{68} \mathrm{He}$ also contended that applying Section Three to him and convicting him of treason would violate the principle of double jeopardy, though he did not say that the Fifth Amendment applied as such to his case.$^{69}$ In making these claims, Davis took the position that Section Three was self-enforcing in Virginia. ${ }^{70}$ Put another way, he said that he lack of any action by Congress to enforce Section Three there did not prevent its application to his defense.

The United States answered that Section Three was not a punishment or, if it was, then exclusion from office was not the exclusive punishment. ${ }^{71}$ To conclude otherwise would mean that the Confederacy's leaders would be free from criminal liability while "the great crowd of humbler offenders, who had but followed the lead of these, their chiefs, were to be left exposed to fines, forfeitures, and imprisonments ... Such a theory of the amendment was in direct reversal of the known national sentiment in this regard."72 The Government added that "[p]robably nothing would more surprise the people of the United States more than to learn that, by adopting amendment 14 , they had repealed all the penalties against treason, insurrection, or rebellion."73 Moreover, the United States denied Davis's claim that Section Three was self-enforcing in Virginia. ${ }^{74}$ There was no Act of Congress enforcing Section Three in that state at the time, and so-the argument went-Davis could not claim any alleged

hold some trials. See Joshua Glick, On the Road: The Supreme Court and the History of Circuit Riding, 24 CARDOZO L. REV. 1753, 1812-18 (2003).

Chief Justice's Chase legal advice to the attorneys of a defendant before him in a criminal trial was quite unusual and would not be tolerated now, but ethical standards were not as rigorous during the nineteenth century. His possible motives are explored shortly. See infra text accompanying notes 102-104.

68. At least one Senator made a similar point when Section Three was proposed. See Cong. Globe, 39th Cong., 1st Sess. 2900 (1866) (statement of Sen. Doolittle) ("[I]f by a constitutional amendment you impose a new punishment upon a class of offenders who are guilty of crime already, you wipe out the old punishment as to them ....").

69. See Davis, 7 F. Cas. at 91 (argument of Mr. Ould).

70. See id. at 90 (argument of Mr. Ould).

71. See id. at 92 (argument of Mr. Beach); id. at 95 (argument of Mr. Dana) (stating that "[t]he phraseology [of Section Three] is not that of penal or criminal law").

72. Id. at 92 (argument of Mr. Beach); see id. at 95 (argument of Mr. Dana) (making a similar point). Davis responded that this point was weak because ordinary citizens in the South were not being prosecuted and there was no chance that they would be. See id. at 98 (argument of Mr. O'Conor).

73. Id. at 95 (argument of Mr. Dana).

74. See id. at 92-94 (argument of Mr. Wells). 
benefit from that constitutional provision.

The question of whether Section Three nullified the Davis treason prosecution was never resolved. Chief Justice Chase and District Judge John Underwood disagreed on this point and the issue was certified for appeal to the Supreme Court. ${ }^{75}$ At the end of the Davis case report, there is a line that states: "THE CHIEF JUSTICE instructed the reporter to record him as having been of opinion on the disagreement, that the indictment should be quashed, and all further proceedings barred by the effect of the fourteenth amendment to the constitution of the United States."76 Shortly thereafter, the question was rendered moot when President Johnson gave Davis a pardon. ${ }^{77}$

\section{B. GRIFFIN'S CASE}

The same judges who were at odds over Section Three's application to the treason case against Jefferson Davis also gave different readings to that provision as applied to Black defendants in Virginia. In 1868, Judge John Underwood granted writs of habeas corpus to three Black defendants who were tried and sentenced by state judges ineligible to sit because of Section Three. $^{78}$ Judge Underwood was an abolitionist who was named to the bench by President Lincoln and was despised by Virginia whites. ${ }^{79}$ His rulings provoked alarm because they implied that many official acts taken in the former Confederate states following the ratification of the Fourteenth Amendment were null

75. See id. at 102

76. Id.

77. See LARSON, supra note 16, at 129; NICOLETTI, supra note 16, at 299-300.

78. See Griffin's Case, 11 F. Cas. 7 (C.C.D. Va. 1869) (No. 5,815); Connally, supra note 16, at 1190-91. The case report describes Judge Underwood's actions before reproducing the arguments of the lawyers and Chief Justice Chase's opinion.

79. See NiCOLETTI, supra note 16, at 182-87; Donnally, supra note 16, at 1186-90. Judge Underwood is a controversial figure who was viewed by his detractors as corrupt and partisan. See 6A Charles FAirman, The Oliver Wendell Holmes DeVise: HisTORY OF THE SUPREME COURT OF THE UNITED STATES: RECONSTRUCTION AND REUNION 1864-1888, at 602 (1971) (calling Underwood a "wayward Judge"); JOHN Niven, SAlmon P. Chase: A BIOGRAPHY 434 (1995) (describing Underwood as a "corrupt and vengeful" judge). Without jumping into that debate, I would note that the now-discredited Dunning school of Reconstruction history, which was sympathetic to white supremacy, was quick to label anyone who fought hard for Black rights as corrupt. See Eric Foner, The Supreme Court and the History of Reconstruction-and Vice-Versa, 112 COLUM. L. REV. 1585, 1589 (2012); see also CHERNOW, supra note 13, at 856-57 (explaining that President Grant's reputation suffered due in part to corruption charges from pro-southern historians). 
and void. Virginia appealed one of the habeas corpus grants to Chief Justice Chase in his capacity as a circuit judge, and in 1869 the Chief Justice reversed Judge Underwood in Griffin's Case. ${ }^{80}$

Griffin's Case deserves close attention as the first major judicial opinion on the Fourteenth Amendment. ${ }^{81}$ On the merits of the Section Three claim, the Chief Justice began with first principles: "What was the intention of the people of the United States in adopting the fourteenth amendment? What is the true scope and purpose of the prohibition to hold office contained in the third section?" 82 Before answering these questions, Chase said that "a construction, which must necessarily occasion great public and private mischief, must never be preferred to a construction which will occasion neither, or neither in so great degree, unless the terms of the instrument absolutely require such preference." 83 With that preface, the Chief Justice turned to consider "what consequences would spring from the literal interpretation" of Section Three, which was that all official acts performed by all ineligible officers after the Fourteenth Amendment was ratified were null and void. ${ }^{84}$ His conclusion was that this view would cause chaos: "No sentence, no judgment, no decree, no acknowledgement of a deed, no record of a deed, no sheriff's or commissioner's sale-in short no official act-is of the least validity. It is impossible to measure the evils which such a construction would add to the calamities which have already fallen upon the people of these [ex-Confederate] states." 85

80. There is nothing distinctive about the facts of Griffin's Case except that Ceasar Griffin was a Black defendant convicted of a felony (shooting with intent to kill). See Griffin's Case, 11 F. Cas. at 22.

81. Griffin's Case was probably the first judicial opinion on the Fourteenth Amendment period, as my research discloses no prior published cases. I will hedge a bit though and say only that this was the first major Fourteenth Amendment opinion. The only secondary source that gives Griffin's Case its due is Professor Fairman's volume on Reconstruction in the Oliver Wendell Holmes Jr. Devise. See FAIRMAN, supra note 79, at 603-07. But his discussion was (in my view) unfairly slanted against Judge Underwood and in favor of Chief Justice Chase.

82. Griffin's Case, 11 F. Cas at 24. Prior to addressing the merits, Chase concluded that the federal habeas corpus statute did apply to Griffin. See id. at 23-24.

83. Id. at 24

84. See id.

85. Id. at 25. In this portion of the opinion, the Chief Justice made two speculative claims. First, he said that some men covered by Section Three might now be officials in Northern states and that their official acts would also be invalid. See id. This claim was farfetched, as ex-Confederates were not plausible candidates for office in the North in 1869 and Chase provided no examples. Second, he offered that Section Three would invalidates the official acts of men who gave aid and comfort to the enemy during the Mexican- 
After addressing the practical aspects of Section Three, Chase next turned to jurisprudential considerations. He said that the preferred reading of a text was one "which best harmonizes the amendment with the general terms and spirit of the act amended. This principle forbids a construction of the amendment, not clearly required by its terms, which will bring it into conflict or disaccord with the other provisions of the constitution." ${ }^{86} \mathrm{He}$ then commented that Section Three was the "only punitive section" in the Fourteenth Amendment, and that "in the judgement of some enlightened jurists, its legal effect was to remit all other punishment." 87 "Enlightened jurists" was code for the Chief Justice himself in the Davis case, as no other judge made such a claim about Section Three. ${ }^{88}$ Chase stated that "those provisions of the constitution which deny to the legislature power to deprive any person of life, liberty, or property, without due process of law, or to pass a bill of attainder or an ex post facto, are inconsistent in their spirit and general purpose with a provision [Section Three] which, at once without trial, deprives a whole class of persons of offices held by them." 89 Though the Chief Justice acknowledged that "no limit can be imposed on the people when exercising their sovereign power in amending their own constitution of government ... it is a necessary presumption that the people in the exercise of that power, seek to confirm and improve, rather than to weaken and impair the general spirit of the constitution." $" 90$

The Chief Justice then offered a solution to the practical and legal difficulties he saw in giving Section Three a literal interpretation: Section Three was not self-executing in a federal case. ${ }^{91}$ The text excluded "from certain offices a certain class of

American War. See id. Again, however, this seems fanciful, as there were only a few examples of treason by Americans during that war and none of them were likely to be public officials in the late 1860 s.

86. Id.

87. Id. at $25-26$

88. The Davis case is the only one in which Section Three was used as a criminal defense, as that was at Chase's suggestion. See supra text accompanying note 67.

89. Griffin's Case, 11 F. Cas. at 26.

90. Id. One important observation about Griffin's Case is that the Chief Justice never questioned the validity of the Fourteenth Amendment. In other words, he did not say anything about the procedural irregularities surrounding the proposal and ratification of that part of the Constitution (for example, the exclusion of the ex-Confederate States from Congress when the Fourteenth Amendment was proposed). This set the template for all subsequent judicial decisions on the Fourteenth Amendment.

91. The Chief Justice was not denying states the power to enforce Section Three on 
persons. Now, it is obviously impossible to do this by a simple declaration ... it must be ascertained what particular individuals are embraced by the definition, before any sentence of exclusion can be made to operate." "To "To accomplish this ascertainment and ensure effective results," he wrote, "proceedings, evidence, decisions, and enforcements of decisions, more or less formal, are indispensable; and these can only be provided for by congress." 93 Chase also said that Section Three could not be self-executing because its language about Congress removing disabilities implied that Congress must act to impose them. ${ }^{94}$ The Chief Justice then noted that Congress did not implement Section Three in Virginia until February 1869, when a Joint Resolution was passed ordering the military commanders there to remove ineligible officers who had not received amnesty from Congress. ${ }^{95}$ The habeas petitions granted by Judge Underwood all predated the Joint Resolution, which meant that the grants were erroneous because the relevant trial judges were not ineligible. ${ }^{96}$

There are many problems with Chief Justice Chase's conclusion, but chief among them was that his position in Griffin's Case contradicted his position in the Davis case. Jefferson Davis contended that Section Three was self-executing and that the absence of legislation on that subject for Virginia (as of December 1868) did not defeat his treason defense. ${ }^{97}$ The Chief Justice must have agreed with this position, otherwise he could not have concluded as he did that Section Three applied to Davis and rendered his treason prosecution unconstitutional. How could Section Three be self-executing for Jefferson Davis but not selfexecuting for Black defendants in the same place at the same time $?^{98}$ The Chief Justice offered no explanation, and my opinion

their own. First, he was discussing federal cases under a writ of habeas corpus. Second, Virginia at the time was an unreconstructed state (in other words, not yet readmitted to Congress) and so there was no legitimate state government there that could act.

92. Griffin's Case, 11 F. Cas. at 26.

93. Id.

94. See id.

95. See id. at 26-27; Res. No. 8, 40th Cong., 15 Stat. 344 (1869) (stating that "the provisions of this resolution shall not apply to persons who by reason of the removal of their disabilities as provided in the fourteenth amendment to the Constitution").

96. See Griffin's Case, 11 F. Cas. at 27.

97. See Case of Davis, 7 F. Cas. 63, 90 (C.C.D. Va. 1867) (No. 3,621a) (argument of Mr. Ould); id. at 92-94 (argument of Mr. Wells) (responding on behalf of the Government to this point).

98. An alternative ground of decision that Chief Justice Chase noted but did not reach was that being tried and sentenced by an ineligible judge was a form of harmless 
is that this pair of results is simply illogical and cannot be explained by legal analysis. But which one of the two decisions reached the correct conclusion?

On balance, Chase's claim that Section Three was not selfenforcing is unpersuasive. First, Section Three contains the same mandatory language ("No person shall ...") as Section One ("No state shall ..."), and there is no doubt that Section One is selfexecuting. ${ }^{99}$ Second, nothing indicates that Congress saw Section Three as anything other than self-executing when the Fourteenth Amendment was drafted. ${ }^{100}$ Third, the practical problems that the Chief Justice sought to avoid were based on speculation, as there was no proof about how many ineligible officials were in Virginia during the relevant period. Fourth, the inconsistency between the 1787 Constitution's criminal law provisions (for example, the Ex Post Facto Clause) and Section Three occur only if Section Three is characterized as a punishment, which is not the only plausible reading. Finally, the fact that Congress legislated about Section Three did not (as the Chief Justice said at one point) strongly imply that Section Three required legislation. ${ }^{101}$

How, then, can we explain Chief Justice Chase's flawed analysis and inconsistency? The first thought might be that he simply treated a white defendant (Davis) differently from a Black defendant (Griffin). But Chase was one of America's greatest antislavery lawyers, and his record refutes any inference of racial animus. ${ }^{102}$ Some scholars argue that Chase harbored presidential

error. See Griffin's Case, 11 F. Cas. at 27. Remarkably, he wrote that "the judges of the supreme court ... unanimously concur in the opinion that a person convicted by a judge de facto acting under color of office, though not de jure, and detained in custody in pursuance of his sentence, cannot be properly discharged upon habeas corpus." Id. The authority for this dictum was not clearly explained, though Virginia had moved in the Supreme Court for a writ of prohibition against Judge Underwood. See id. at 8.

99. Chief Justice Chase did not comment in Griffin's Case on whether any parts of the Fourteenth Amendment were self-executing, but no subsequent decision denied that Section One was self-executing.

100. To conclude otherwise would mean that Section Three applied in some states but not in others until the broad enforcement provisions in the First Ku Klux Klan Act were enacted in 1870. Before that point, Congress enforced Section Three in a haphazard way that would be hard to explain on the ground that they wanted the provision enforced in some places but not in others.

101. See Griffin's Case, 11 F. Cas. at 26-27. In general, enacting enforcement legislation does not imply that legislation is required. Nor did the enforcement provision in Section Five of the Fourteenth Amendment imply that the other sections were not selfexecuting. If so, then Section One could also be read as not self-executing.

102. For an excellent popular history on Chase's background in the antislavery moment, see Doris Kearns Goodwin, Team of Rivals: The Political GeniUs of 
ambitions and that his actions in the Davis trial are best seen as furthering those goals rather than as applying the law fairly. ${ }^{103} \mathrm{~A}$ third idea from these scholars is that the Chase was concerned that white Southerners would not accept the legitimacy of the Fourteenth Amendment, and so he applied the text to help the ex-Confederate President and not to help freed slaves, as a way of convincing skeptical whites to accept the text. ${ }^{104}$

While one or more of these extrajudicial explanations may work, there were jurisprudential ideas at play in Griffin's Case. The thrust of the Chief Justice's opinion was that the Fourteenth Amendment should not be read as a revolutionary change, both in practical terms and in relation to the 1787 Constitution. ${ }^{105}$ The desire to tame new constitutional text reflects a cautious judicial instinct that was reiterated by the Supreme Court in its first Fourteenth Amendment decision-the Slaughter-House Cases. ${ }^{106}$ The Court there declined to read Section One as "so great a departure from the structure and spirit of our institutions" that "radically changes the whole theory of the relations of the State and Federal governments to each other and of both these

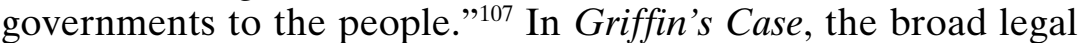
change to be avoided was the imposition of what Chief Justice Chase saw as a bill of attainder, an ex post facto law, or a violation of due process, whereas in Slaughter-House the concern was states' rights. ${ }^{108}$ In both cases, however, there was a concerted effort to limit the Fourteenth Amendment in favor of the principles of the 1787 Constitution, which continued after Slaughter-House. ${ }^{109}$ The problem with this approach is that the Fourteenth Amendment was a radical text in many respects, which sometimes made a cautious reading wrong. With respect to

ABRAHAM LINCOLN 108-16 (2005).

103. See LARSON, supra note 16, at 126-28; NICOLETTI, supra note 16, at 194-95, 293 94. Similar political allegations were made about how the Chief Justice handled President Andrew Johnson's impeachment trial. See STEWART, supra note 36, at 178-79.

104. See NiCOLETTI, supra note 16, at 295-96; Davis, supra note 16, at 74.

105. The same desire to avoid rocking the boat might explain the Chief Justice's reading of Section Three in Jefferson Davis's case, where caution counseled against a divisive treason trial.

106. 83 U.S. (16 Wall.) 36 (1873).

107. Id. at 78. Chief Justice Chase did dissent in Slaughter-House. See id. at 111 (Field, J., dissenting) (stating that the Chief Justice joined his opinion).

108. There was no federalism issue as such in Griffin's Case because in 1869 Virginia was still an unreconstructed state under federal military rule.

109. See, e.g., The Civil Rights Cases, 109 U.S. 3 (1883); United States v. Cruikshank, 92 U.S. 542 (1876). 
Section Three, Judge Underwood was more consistent and more faithful to the text than Chief Justice Chase.

A second inescapable thought is that Griffin's Case (in combination with Davis's case) heralded a Fourteenth Amendment that would be read more favorably for whites than for Blacks. Perhaps that was an inevitable consequence of downplaying the radical nature of Reconstruction. Another explanation, though, is that the Chief Justice approached Section Three as a provision about legal neutrality rather than about fighting the Slave Power and white supremacy. Seen in that light, Section Three could be read to aid the leader of the Slave Power and to reject the claims of a Black defendant. Whether the Fourteenth Amendment should be viewed as embodying an "anticlassification" or an "anti-subordination" principle is commonplace in modern commentary, but the roots of that dispute are found in Griffin's Case and in the subsequent debate over Section Three amnesty. ${ }^{110}$

\section{The First Ku KluX Klan ACt And Zebulon VAnCE}

A year after Griffin's Case was decided, Congress took action to enforce Section Three more generally. ${ }^{111}$ In response to white supremacist violence and voter intimidation throughout the South, Congress enacted the First Ku Klux Klan Act (also known as the Enforcement Act of 1870) to protect voting rights recently guaranteed by the Fifteenth Amendment. ${ }^{112}$ Two sections of that statute focused on removing ineligible officials who might be obstructing Black voting. ${ }^{113}$ Section Fourteen of the Act said that

110. See, e.g., Reva B. Siegel, From Colorblindness to Antibalkanization: An Emerging Ground of Decision in Race Equality Cases, 120 YALE L.J. 1278, 1282-83 (2011); infra text accompanying notes $141-143,156$.

111. There is no indication that Congress was responding directly to Chief Justice Chase's opinion, as I can find no references to Griffin's Case in the Congressional Globe.

112. See First Ku Klux Klan Act, ch. 114, 16 Stat. 140 (1870). This enforcement authority was repealed in the 1940s. After the violence at the Capitol, legislation was introduced to create new Section Three enforcement authority. See H.R. 1405, 117th Cong. (2021).

113. Not much was said about the Section Three provisions. One Senator criticized them for turning ex-Confederate leaders into martyrs. See Cong. GLOBE, 41st Cong., 2d Sess. 3661 (1870) (statement of Sen. Sawyer) ("If the public sentiment of Mississippi or Georgia is so thoroughly disloyal as to render the election of men like these probable, then our reconstruction is a failure, and time only will relieve us from the evils legislation has sought in vain to cure. But if, as I believe, the vast majority of the people of those States care little for Jefferson Davis ... or any other rebel leader, except as they are compelled to think of them as under the ban of ineligibility to public office, when you remove from 
federal prosecutors had a duty to bring quo warranto actions against state executive officials and judges covered by Section Three. ${ }^{114}$ Quo warranto (literally, by what warrant) was a common-law writ challenging an officeholder's right to hold his position. ${ }^{115}$ Section Fourteen also provided that any quo warranto actions should receive priority on the docket of a federal court. ${ }^{116}$ Lastly, Section Fifteen of the Act declared that any person who knowingly held an office while ineligible due to Section Three was guilty of a misdemeanor and subject to a year in prison or a $\$ 1,000$ fine. ${ }^{117}$

The Grant Administration responded by filing quo warranto actions and bringing indictments under the Klan Act. ${ }^{118}$ The best information on these proceedings comes from Tennessee, where both types of cases were brought against the state Attorney General and three state Supreme Court Justices. ${ }^{119}$ One of the

them the badge of distinction which they wear and parade they will sink into that insignificance which is the common fate of the defeated leaders of a lost cause."). Another Senator rejected the idea of Section Three amnesty, stating: "For my part it appears to me time enough to talk of amnesty when the Kuklux organization shall have ceased to exist and everybody, whether exalted or humble may enjoy the pursuit of peace and happiness without molestation." Id. at 3669 (statement of Sen. Spencer).

114. See First Ku Klux Klan Act, § 14 ("[W]henever any person shall hold office, except as a member of Congress or of some State legislature, contrary to the provisions of the third section of the fourteenth article of amendment of the Constitution of the United States, it shall be the duty of the district attorney of the United States for the district in which such person shall hold office ... to proceed against such person, by writ of quo warranto, returnable to the circuit or district court of the United States in such district, and to prosecute the same to the removal of such person from office ...."). Members of Congress were excluded because, as we shall see in a moment, each House was fully capable of excluding a member-elect who was ineligible under Section Three. See infra text accompanying notes $124-126$. State legislators were not included because they presumably did not pose (or seem to pose) the kind of threat to voting rights that executive officials or judges did.

115. See, e.g., Newman v. United States ex rel. Frizzell, 238 U.S. 537, 544-45 (1915).

116. See First Ku Klux Klan Act, $\S 14$ ("[A]ny writ of quo warranto so brought ... shall take precedence of all other cases on the docket of the court to which it is made returnable, and shall not be continued unless for cause proved to the satisfaction of the court.").

117. See id. § 15 ("[A]ny person who shall hereafter knowingly accept or hold any office under the United States, or any State to which he is ineligible under the third section of the fourteenth article of amendment of the Constitution of the United States, or who shall attempt to hold or exercise the duties of any such office, shall be deemed guilty of a misdemeanor against the United States, and, upon conviction thereof before the circuit or district court of the United States, shall be imprisoned not more than one year, or fined not exceeding one thousand dollars [ $\$ 1,000]$, or both, at the discretion of the court.").

118. See Elliott, supra note 10, at 24-26.

119. See id. at 25 . The cases were widely covered by local newspapers. See, e.g., The Supreme Court and the Fourteenth Amendment to be Enforced, KNOXVILlE CHRON., Oct. 
ineligible Justices resigned, but the others remained and the actions against them were dismissed once Congress granted broad Section Three amnesty in $1872 .{ }^{120}$ Elsewhere in the South, the record on the Administration's enforcement effort is sketchy and merits more research. ${ }^{121}$ In many instances, the relevant official may have simply quit rather than risk criminal sanctions, and a resignation would not have typically left behind traces. Nevertheless, there is one reported Section Three criminal case from the federal circuit court in North Carolina, ${ }^{122}$ and one newspaper report in Virginia on the dismissal of an ineligible postmaster there. ${ }^{123}$

Meanwhile, the Senate itself enforced Section Three by refusing to seat a member-elect on the ground that he was ineligible. Zebulon Vance was the wartime Governor of North Carolina and was elected by the State Legislature to the Senate in $1871 .^{124}$ The Senate excluded Vance, who had served in the House of Representatives before the Civil War and was thus subject to Section Three. ${ }^{125}$ The seat remained vacant for about a year

23, 1870, at 1; Political Disabilities - The Question in Federal Court, NASHVILLE UNION \& AM., Oct. 20, 1870, at 2; Enforcing the Fourteenth Amendment, FAYETTEVILLE OBSERVER, Oct. 13, 1870, at 2.

120. See Elliott, supra note 10, at 26.

121. Most of the available information on the Section Three litigation comes from newspaper accounts. I am uncertain if the online records of Tennessee papers from that period are simply better than for other ex-Confederate States or if Tennessee for some reason was a focal point for Section Three enforcement. Due to the pandemic, I could not conduct newspaper research that went beyond online sources.

122. See United States v. Powell, 27 F. Cas. 605 (C.C.D. N.C. 1871) (No. 16,079) (charging a jury that Section Three's language on "engaged in insurrection or rebellion" required a voluntary act by the official who was allegedly disqualified). John Bingham said that there were seventy pending criminal cases across the country as of December 1870 and that he was opposed to granting amnesty to any of those men. See CONG. GLOBE, 41st Cong., 3d Sess. 204 (1870) (statement of Rep. Bingham). The Amnesty Act of 1872, though, did not exclude those who were being prosecuted under Section 15 of the First Ku Klux Klan Act.

123. See A Case Under the Fourteenth Amendment, RichmOND DAILY DisPatch, June 7,1871 , at 1 .

124. See, e.g., Clement Dowd, Life of Zebulon B. VANCE 218 (Charlotte, N.C., Observer Printing \& Publ'g House, 1897) (describing Vance's exclusion by the Senate due to Section Three of the Fourteenth Amendment). The House of Representatives voted not to exclude a member-elect who was challenged on Section Three grounds. See Myles S. Lynch, Disloyalty \& Disqualification: Reconstructing Section 3 of the Fourteenth Amendment, 30 WM. \& MARY BILL RTS. J. (forthcoming 2021) (manuscript at 53-54), https://papers.ssrn.com/sol3/papers.cfm?abstract id=3749407.

125. See BLAINE, supra note 3, at $531 \mathrm{n} .1$. It is unclear if the North Carolina Legislature selected Vance hoping that Congress would remove his disability or did so as a defiant rejection of the Fourteenth Amendment, though Blaine thought the latter was 
before Vance resigned as Senator-elect, evidently concluding (incorrectly) that no congressional amnesty was forthcoming. ${ }^{126}$ When Horace Greeley won the Democratic presidential nomination in 1872, he dwelt on Vance's exclusion to call for universal Section Three amnesty as part of his campaign against President Grant. ${ }^{127}$

Accordingly, Section Three was highly visible after the Fourteenth Amendment was ratified as a tool to reorder politics in the ex-Confederate States. At the same time, though, Griffin's Case suggested that the sweeping implications of Section Three might lead to buyer's remorse from northern whites. That moment soon arrived.

\section{PART III. FORGIVENESS}

This Part reviews Congress's decision to remove most of the Section Three disabilities in 1872 . Though amnesty partly resulted from fatigue in the North with ongoing sectional strife, President Grant and Congress also concluded that Section Three was not helping Reconstruction and could be making matters worse by giving white Southerners an excuse to aid the Ku Klux Klan. But Senator Charles Sumner brought the amnesty bill to a halt by proposing a sweeping civil rights amendment that would have barred racial segregation in churches, public schools, and many businesses. ${ }^{128}$ The ensuing discussion was notable in part due to the participation of the first Black Representatives, who brought their distinctive (if tragic) voices to the debate before acquiescing in unilateral mercy for whites. ${ }^{129}$

the truth. See id.

126. After amnesty was granted, Vance was elected to the Senate in 1879 and served until his death in 1894. See ANNE M. BUTLER \& WENDY WOLFF, United STATES SENATE ELECTION, EXPULSION, AND CENSURE CASES, 1793-1990, at 169 (1995); see also BLAINE, supra note 3, at 641 (noting Vance's election in 1878).

127. See BlAINE, supra note 3 , at $531 \mathrm{n} .1 ; i d$. at 641 (stating that Vance became well known in the North due to Greeley's references to the exclusion "as an illustration of Republican bigotry"); see also CHERNOW, supra note 13, at 741-44 (describing Greeley's background and swerve in favor of amnesty heading into the campaign).

128. See DonALD, supra note 12, at 531 (describing the substance of Sumner's amendment); McConnell, supra note 12, at 1049-54 (describing the procedural history of Sumner's amendment).

129. See BLAINE, supra note 3, at 515 ("The colored representatives, who had been slaves, were willing to release their late masters from every form of disability, but the immediate friends of the masters were unwilling to extend the civil rights of the colored man. So far as chivalry, magnanimity, charity, Christian kindness, were involved, the colored men appeared at an advantage."); CHERNOw, supra note 13, at 703 (noting that 


\section{A. THE GROWING CALL FOR AMNESTY}

Amnesty was on the table before the Fourteenth Amendment was even ratified. In June 1868, Congress enacted legislation to remove Section Three disabilities from about 1,000 men, including a Representative-elect from Tennessee. ${ }^{130}$ The Republican Party platform in 1868 stated: "[W]e favor the removal of the disqualifications and restrictions imposed upon the late rebels, in the same measure as the spirit of disloyalty will die out, and as may be consistent with the safety of the loyal people." 131 Until 1872, Congress relied on private bills to remove Section Three disabilities from thousands of individuals. ${ }^{132}$ According to James G. Blaine, the unwritten rule was that "everyone who asked for [amnesty], either through himself or his friends, was freely granted remission of penalty." 133 Using private bills for Section Three exceptions was criticized, though, on the ground there was no principle at work except political favoritism. ${ }^{134}$ Moreover, the sheer number of personal amnesty requests soon overwhelmed Congress and led to calls for general Section Three amnesty legislation. ${ }^{135}$ As John Bingham told the

six Black Congressman were elected in 1870) see infra text accompanying notes 144-148, 182-186.

130. See Act of June 25, 1868, ch. 83, 15 Stat. 361, 361-67; Act of June 19, 1868, ch. 62, 15 Stat. 360 (removing disabilities from Roderick R. Butler of Tennessee); BLAINE, supra note 3, at 512. A fair question here is how Congress could remove disabilities before Section Three was ratified, but that can be chalked up as one more anomaly among many with respect to the Fourteenth Amendment's proposal and ratification.

131. See 1 NATIONAL PARTY PlatForms, supra note 11, at 40 (quoting the 1868 Republican Platform). By contrast, the 1868 Democratic Platform called for "[a]mnesty for all past political offenses." Id. at 37.

132. See, e.g., Priv. Act of December 14, 1869, ch. 1, 16 Stat. 607. The practice prior to 1872 was that Section Three relief came in the form of legislation that was signed by the President.

133. BLAINE, supra note 3, at 512; see id. ("[D]uring the two years [of the Forty-first Congress] thirty-three hundred participators in the rebellion-among them some of the most prominent and influential-were restored to the full privileges of citizenship ....").

134. See Cong. Globe, 42d Cong., 2d Sess. 240 (1871) (statement of Sen. Stewart) ("It is impossible for Congress to investigate and pass upon the cases of individuals with any degree of fairness and impartiality."); $c f$. CONG. GLOBE, 42d Cong., 1st Sess. 3180 (1872) (statement of Sen. Boreman) ("It seems as if we were not treating these persons all alike when the behavior, the conduct of the latter [who did not receive an exemption], is as good as that of the former [who did receive an exemption].").

135. See Cong. Globe, 42d Cong., 2d Sess. 241 (1871) (statement of Sen. Hill) (explaining that point of view); BLAINE, supra note 3, at 512-13 ("The impossibility of examining into the merits of individuals by tens of thousands, and of establishing the quality and degree of their offenses, was so obvious that representatives on both sides of the House demanded an Act of general amnesty, excepting therefrom only the few classes whose names would lead to discussion and possibly to the defeat of the beneficent 
House of Representatives in December 1870: "The question now, is, whether we shall not take another step forward and remove the disabilities of all persons to hold office, provided the people choose to elect them to office, save those who were the chiefs in organizing and aiding the rebellion." 136

The momentum for amnesty was also in reaction to a white terror campaign in the South. In 1871, Congress enacted the Second Ku Klux Klan Act and suspended the writ of habeas corpus in some portions of the former Confederacy. ${ }^{137}$ One could argue that the sticks being wielded to defeat this latest insurrection should be coupled with the carrot of Section Three relief to persuade white elites to stop supporting the Klan. Members of Congress argued that Section Three should be neutered because the exclusions were accomplishing nothing or were exacerbating white anger in the South. ${ }^{138}$ Meanwhile, a faction of "Liberal Republicans" supported amnesty as part of a broader critique of Reconstruction that, in essence, called on President Grant to end his support for the freed slaves and allow ante-bellum elites to regain power in the South. ${ }^{139}$ Not surprisingly, some Republicans firmly disagreed with that sentiment and contended that violent white resistance should not be rewarded. ${ }^{140}$

measure.").

136. Cong. Globe, 41st Cong., 3d Sess. 203 (1870) (statement of Rep. Bingham). Bingham estimated that about 20,000 people were still subject to Section Three. See id.

137. See Act of Feb. 28, 1871, ch. 99, 16 Stat. 433; Amanda L. Tyler, Habeas CORPUS IN WARTIME: From THE TOWER OF LONDON TO GUANTANAMO BAY 199-207 (2017).

138. See CONG. Globe, 42d Cong., 1st Sess. 63 (1871) (statement of Rep. Farnsworth) ("We have had these disqualifications existing for a great length of time. Disorders have not ceased in consequence. Will, then, the continuance of these disqualifications help to restore order? I think not."); id. at 103 (statement of Rep. Buckley) ("Mr. Speaker, we never can put down violence and outrage in the South by the mere continuance of political disabilities."); id. (statement of Rep. Blair) ("I would appeal to the Republicans of this House; I would appeal to the colored Representatives here to say why the withholding of this measure today, refusing to remove these disabilities, will remedy the evil of which they speak in the southern States?").

139. See DONALD, supra note 12, at 517-18, 529-30; cf. MAGLIOCCA, supra note 51, at 164 (explaining that the rift in the Republican Party contributed to John Bingham's defeat in his 1872 bid for another term in the House of Representatives).

140. See Cong. Globe, 42d Cong., 1st Sess. 105 (1871) (statement of Rep. Hoar) ("[I]t is said that it is necessary to adopt this bill for the pacification of the South. But, on the contrary, does not the experience of the past five years show that just as fast and just in proportion as we have relieved disabilities, just so fast these outrages and murders of loyal citizens have increased?"). 
One noteworthy feature of this unfolding conversation was the claim by amnesty proponents that Section Three was in tension with Section One of the Fourteenth Amendment. When a North Carolina sheriff attempted to challenge his exclusion in the Supreme Court, he said that Section Three "is an assault upon an immunity and privilege granted to us by the 1st section of that same amendment." ${ }^{141}$ More than one Representative put the issue in terms of equal protection, declaring that "we ought first of all things to put all men, white as well as black, upon terms of equality before the law ... If there be anything which will put down the disturbances which are said to exist in the southern States it will be the full and perfect restoration to all men of equal rights and privileges." 142 Section Three applied to only white men and did take away a basic right from them, though for obvious cause. The idea that equality justified Section Three amnesty rested in part on a premise that the Fourteenth Amendment should be read more as an anti-classification text than as an anti-subordination text, as may be implied by Chief Justice Chase's reasoning in Davis and in Griffin's Case. ${ }^{143}$

Robert B. Elliott, one of the first Black men elected to Congress, issued a strong challenge to that premise. Elliott emigrated to the United States in the 1860s, but quickly established himself as a leading Republican in South Carolina. ${ }^{144}$ Upon his arrival in the House of Representatives in March 1871, Elliott jumped into the fray immediately with a speech stating that removing Section Three disabilities was "nothing but an attempt to pay a premium for disloyalty and treason at the expense of loyalty." $145 \mathrm{He}$ ridiculed equating the "disenfranchised old man and his servant, or slave, who today holds office or may do so."146

141. Worthy v. Commissioners, 76 U.S. (9 Wall.) 611, 613 (1869). The Court dismissed the sheriff's appeal because no constitutional challenge was raised in state court. See id. ("[T]his right does not appear to have been set up, or specially claimed in the State court; and this is essential to jurisdiction here.").

142. Cong. Globe, 42d Cong., 1st Sess. 62 (1871) (statement of Rep. Beck); see id. at 41st Cong., 3d Sess. 203 (1870) (statement of Rep. Bingham) (arguing that the Equal Protection Clause was inconsistent in spirit with maintaining Section Three disabilities for most ex-Confederates).

143. See supra text accompanying note 110.

144. See generally PEgGY LAMSON, THE Glorious FAILURE: Black CONGRESSMAN ROBERT BROWN ELLIOTT AND THE RECONSTRUCTION IN SOUTH CAROLINA (1973). Elliott served in the state's constitutional convention and was elected to the House before he turned 30 .

145. CONG. GlobE, 42d Cong., 1st Sess. 102 (1871) (statement of Rep. Elliott).

146. Id. 
To grant relief to that "poor old man," Elliott explained, would be "taken as evidence of the fact that this Congress desires to hand over the loyal men of the South to the tender mercies of the rebels who today are murdering and scourging the loyal men of the southern States." ${ }^{147}$ He concluded on a personal note: "I speak not today in behalf of the colored loyalists of the South alone ... I represent here a constituency composed of men whose complexions are like those of gentlemen around me as well as men whose complexions are similar to my own." 148 For a House of Representatives that lacked a Black member until 1871, Elliott's statement on the Fourteenth Amendment was a remarkable moment. Nevertheless, the House passed a partial amnesty bill by a greater than two-thirds margin. ${ }^{149}$

Months after the House acted, President Grant issued his Annual Message (the term then used for the State of the Union) and declared his support to amnesty. "More than six years having elapsed since the last hostile gun was fired between the armies then arrayed against each other," the President said, "it may well be considered whether it is not now time that the disabilities imposed by the fourteenth amendment should be removed." 150 "When the purity of the ballot is secure," he said, "majorities are sure to elect officers reflecting the views of the majority. I do not see the advantage or propriety of excluding men from office merely because they were before the rebellion of standing and character sufficient to be elected to positions requiring them to take oaths to support the Constitution, and admitting to eligibility those entertaining precisely the same views, but of less standing in their communities." 151 Grant concluded that "[i]f there are any great criminals, distinguished above all others for the part they took in opposition to the Government, they might, in the judgment of Congress, be excluded from such an amnesty." ${ }^{152}$

147. Id.

148. Id. at 103 (statement of Rep. Elliott).

149. See id. at 562-63. The House bill contained exceptions that were modified before the final legislation was enacted a year later. See BLAINE, supra note 3, at 512 (describing the House bill).

150. Ulysses S. Grant, Third Annual Message (Dec. 4, 1871), in 9 Messages, supra note 11 , at 4096,4107

151. Id.; see id. ("It may be said that the former violated an oath, while the latter did not; the latter did not have it in their power to do so. If they had taken this oath, it cannot be doubted they would have broken it as did the former class.").

152. Id. The President's reference to criminals is some support for the view that Section Three was a punishment rather than a qualification. 
The President wisely read Northern public opinion with an eye toward the upcoming election, but his position also reflected a shift in attitude about the nature of representation. Section Three can be read as saying that there was an "advantage or propriety" in excluding men from office because of their personal attitudes. President Grant took the view that elected representatives were not independent and just registered the views of their constituents: "Majorities are sure to elect officers reflecting the views of the majority." As one House member stated: "You cannot prevent any idea being represented by keeping out of office any particular man or set of men. We all know that." ${ }^{153}$ But the Framers of the Fourteenth Amendment did not know that or take that position. Experience from 1866 and 1871 taught that lesson, but that reality did not necessarily mean that the Section Three disabilities were unwarranted.

Following the President's endorsement, the Senate took up Section Three legislation. Some Republicans continued to dismiss amnesty, with one saying that this would not "change the spirit of the rebels and secure their support to the Government." 154 Another replied that Section Three disabilities should be removed because they "created great irritation and accomplished very little good." 155 Senator Trumbull made the equality argument for amnesty, stating that all believed "in equality among the citizens of this country. Now here is a bill placing upon an equality, so far as the right to hold office is concerned, those who have been disqualified by reason of their participation in the rebellion." 156 Another Senator took a more pragmatic view: "I shall vote for this bill; not as a measure of justice to the South or of equality among citizens. I vote for it as a safe and sound measure of public policy ... In passing this bill the less we say about justice or equality the better." 157

153. Cong. Globe, 42d Cong., 1st Sess. 62 (1871) (statement of Rep. Beck).

154. Cong. Globe, 42d Cong., 2d Sess. 239 (1871) (statement of Sen Buckingham); see id. ("Let us not, then, attempt to secure tranquility by taking counsel of our enemies, or by making haste to restore them to positions to power.").

155. Id. at 240 (statement of Sen. Stewart).

156. Id. at 245 (statement of Sen. Trumbull); see id. at 246 (statement of Sen. Alcorn) ("[A]n inequality clearly upon its face does there exist and is there maintained by the Congress of the United States.").

157. Id. at 248 (statement of Sen. Wilson); see id. at 279 (statement of Sen. Kellogg) ("The passage of an amnesty bill like the one under consideration will strengthen [Republicans] in the South, if for no other reason [than] because it will take from the Democratic party the strongest argument that they can use against us ...."). 


\section{B. THE CIVIL RightS AMENDMENT}

One Senator who was eager to say more about justice and equality was Charles Sumner. Famed for his antislavery stance and tireless work on behalf of racial equality, Senator Sumner announced in December 1871 that he would propose an amendment to the amnesty bill that guaranteed civil rights for the freed slaves that went beyond the Civil Rights Act of 1866. ${ }^{158}$ The Sumner amendment prohibited discrimination on the basis of race by common carriers, innkeepers, theaters, churches, public schools, juries and cemeteries. ${ }^{159}$ "[N]ow that it is proposed that we should be generous to those who were engaged in the rebellion," he told the Senate, "I insist upon justice to the colored race everywhere throughout this land." 160 In part, Sumner was employing a time-honored tactic of attaching something to a popular bill with the thought that the entire bill would pass. The problem was that an amnesty bill was a special act requiring a twothirds vote to pass rather than a simple majority. But Sumner's effort to put his civil rights bill on the floor was stymied by the Senate Judiciary Committee, so amending the Section Three bill was his only realistic option. ${ }^{161}$

More important, Sumner explained that there was a logical connection between extending civil rights for Blacks and removing disabilities for whites. In Sumner's first major speech on the amendment, he stated: "Each is the removal of disabilities, and each is to operate largely in the same region of country. Nobody sincerely favoring generosity to rebels should hesitate in justice to the colored race. According to the maxim in chancery, 'Whoso would have equity must do equity."'162 Furthermore, "[e]ach is a measure of reconciliation, intended to close the issues of the war; but these issues are not closed unless each is

158. See id. at 240 (statement of Sen. Sumner); see also Civil Rights Act of 1866, ch. 31, 14 Stat. 27, 27-30 (prohibiting discrimination against Blacks with respect to core common-law rights such as contracts and property ownership).

159. Cong. Globe, 42d Cong., 2d Sess. 243-44 (1871). This Article does not discuss the ins-and-outs of Sumner's civil rights proposal apart from its relationship to amnesty.

160. Id. at 240 (statement of Sen. Sumner).

161. See McConnell, supra note 12, at 1049-52 (describing the proposal and the Senate Judiciary Committee's opposition). The Senate first debated whether the amendment was germane before concluding that the answer was yes. See id. at 1053-54. Then the amendment was voted down by one vote. See id. at 1054. Senator Sumner continued to press his amendment, though, when the Senate reconvened in January 1872. See id.

162. Cong. Globe, 42d Cong., 2d Sess. 386 (1872) (statement of Sen. Sumner). 
adopted."163 "Hereafter," Sumner concluded, "the rebels should remember that their restoration was associated with the Equal Rights of all, being contained in the same great statute."164 Sumner's amendment put the equality argument for removing the Section Three disabilities to the test, as advocates for that point of view would have to explain why that equality did not also apply to Blacks. ${ }^{165}$

The Senate spent much of January and February debating civil rights, but every so often someone could comment on the Section Three issue. For instance, one accused Sumner of bringing civil rights forward as a poison pill to defeat amnesty. ${ }^{166}$ But another supported Sumner's link between those two issues as a fair deal for the white South: "We give you amnesty; you give what you ought never to have withheld, a full communion upon the broad ground of equal rights with your fellow-men." 167 Other Senators were against amnesty and for civil rights, with one stating that "[1]et us not say to future generations that these [rebel] men did no wrong ... and of again being returned to the highest positions in the Government."168 Carl Schurz, one of the leading Liberal Republicans, took the opposite tack and disagreed "that the system of disabilities must be maintained for a certain moral effect ... Methinks that the American people have signified their disapprobation of the crime of rebellion in a far more pointed manner. They sent against the rebellion a million armed men." ${ }^{169}$ Schurz wound up his remarks by repeating the equality argument for Section Three amnesty, arguing that "when this is a truly a people of citizens equal in their political

163. Id.

164. Id.

165. Cf. DONALD, supra note 12 , at 535 (describing the political dilemma facing Republicans in either alienating Southern Blacks or Southern whites, and stating: "After much consultation, Grant's friends in the Senate decided to support both amnesty and civil rights - in the expectation that both would fail.").

166. See Cong. Globe, 42d Cong., 2d Sess. 490 (1872) (statement of Sen. Sawyer); id. (stating that he supported Section Three relief because "I would take away from them a badge of distinction between them and their neighbors which they hold up to public gaze as a grievance.").

167. Id. at 495 (statement of Sen. Nye); see id. at 877 (statement of Sen. Harlan) ("I doubt whether rebels who are still opposed to equality of civil rights between themselves and [the] Union men then ought to be relieved from [the] only political disabilities under which they labor - the right to hold office.").

168. Id. at 524 (statement of Sen. Morton).

169. Id. at 700 (statement of Sen. Schurz); see DONALD, supra note 12, at 518 (noting Schurz's leadership in the Liberal Republican faction). 
rights, it will then be easier to make it also a people of brothers." 170

At the conclusion of this lengthy debate, the Senate deadlocked. Sumner's amendment resulted in a tie vote that was broken by the Vice-President in favor of the civil rights provisions. ${ }^{171}$ With the amendment, though, the amnesty bill failed to garner the necessary two-thirds vote. ${ }^{172}$ The stalemate continued until May 1872, with Sumner making one final plea against removing "the disabilities of a few persons who drew their swords against their country" without removing "the larger disabilities which now attach to the much larger number of people." ${ }^{173}$ But the Senate finally decided to pass Section Three amnesty without civil rights. ${ }^{174}$ One possible explanation for that change was that the Liberal Republicans held their convention in May, nominated Horace Greeley, and in their platform demanded "the immediate and absolute removal of all disabilities imposed on account of the Rebellion, which was finally subdued seven years ago, believing that universal amnesty will result in complete pacification in all sections of the country." 175 Greeley's political threat to divide Republicans might have spurred the party's members in Congress to do something to take some of the wind out of his sails. ${ }^{176}$

The result was a partial amnesty. Section Three disabilities were retained for "Senators and Representatives of the thirtysixth and thirty-seventh Congresses, officers in the judicial, military, and naval service of the United States, heads of

170. Cong. Globe, 42d Cong., 2d Sess. 703 (1872) (statement of Sen. Schurz)

171. See DonALD, supra note 12, at 539; McConnell, supra note 12, at 1054.

172. See DONALD, supra note 12, at 539; McConnell, supra note 12, at 1055; see also 2 BLAINE, supra note 3, at 513 ("[T]he Democratic leaders were not willing to accept amnesty for their political friends in the South, if at the same time they must take with it the liberation of the colored man from odious personal discriminations.").

173. Cong. GLOBE, 42d Cong., 2d Sess. 3264 (1872) (statement of Sen. Sumner); see McConnell, supra note 12, at 1055-58 (describing the procedural background).

174. See DONALD, supra note 12, at 544-45; McConnell, supra note 12, at 1055. This result came about due to a procedural sleight-of-hand that occurred while Senator Sumner was not on the floor. See DONALD, supra note 12, at 546-47; McConnell, supra note 12, at 1058-60.

175. 1 NATIONAL PARTY PLATFORMS, supra note 11, at 44 .

176. The precise sequence of events was that the House of Representatives passed the revised version of partial amnesty in May 1872 on a voice vote. See BLAINE, supra note 3, at 513-14; see also CONG. GLOBE, 42d Cong., 2d Sess. 3381-83 (1872). Then the Senate, over Sumner's objection, passed the House bill shortly thereafter. See BLAINE, supra note 3 , at $514-15$. In the text, I altered the order for the sake of clarity. 
departments, and foreign ministers of the United States." 177 Most notably, this left Jefferson Davis out, as he was a Senator in the Thirty-Sixth Congress. ${ }^{178}$ Greeley's call for universal amnesty now became a political problem, because Section Three relief for Davis and the highest ex-Confederates was still deeply unpopular in the North. ${ }^{179}$ But one immediate consequence of amnesty was that suffrage was restored to whites who lived in the four states that disenfranchised men subject to the Section Three exclusion. ${ }^{180}$ Whether this changed any electoral results in those four states afterwards is difficult to assess. What is clear is that some ex-Confederates that the Fourteenth Amendment was designed to exclude returned to Congress. Most notably, Alexander Stephens came back into the House of Representatives in $1873 .{ }^{181}$

Before the Senate acted, another Black Representative rose to plead for mutual concessions. Joseph Rainey, who like Robert Elliott represented South Carolina, explained that: "It is not the disposition of my constituency that those disabilities should longer be retained on them." "We are desirous, sir, of being magnanimous," Representative Rainey said, "it may be that we are so to a fault; nevertheless, we have open and frank hearts toward those who were our former oppressors and taskmasters." "183 "[W]hile we are willing to accord them their enfranchisement, and here to-day give our votes that they may be amnestied," he went on, "we would say to those gentlemen on the other side ... that there is another class of citizens in this country,

177. Act of May 22, 1872, ch. 193, 17 Stat. 142 (1872)

178. See GoodwIN, supra note 102, at 301 (describing Senator Davis's Farewell Address in January 1861 announcing his resignation).

179. A colorful example came in 1876 , when a bill was introduced to remove the Section Three disabilities that remained after the 1872 amnesty. Republicans attempted to amend the bill to waive disabilities for everyone except Jefferson Davis, as a way of putting Democrats on the spot. See BLAINE, supra note 3, at 554-55. The amendment was never voted on because Davis's status was still too controversial, and no amnesty was extended at that time.

180. See supra text accompanying notes 55-57.

181. See BLAINE, supra note 3 , at 546-47.

182. Cong. Globe, 42d Cong., 2d Sess. 3382 (1872) (statement of Rep. Rainey); see BLAINE, supra note 3, at 513 ("The Democrats were now to witness an exhibition of magnanimity in the colored representatives which had not been shown towards them."); see generally CYRIL OUTERBRIDGE PACKWOOD, DETOUR - BERMUDA, DESTINATIONU.S. House of RePresentatives: The LifE of JosePh HAYNe Rainey (1977) (discussing the Congressman's life).

183. CONG. Globe, 42d Cong., 2d Sess. 3382 (1872) (statement of Rep. Rainey). 
who have certain dear rights and immunities which they would like you, sirs, to remember and respect." 184 "We now invoke you, gentlemen," Rainey explained, "to show the same magnanimity and kindly feeling towards us - a race long oppressed, and in demonstration of this humane and just feeling give, I implore you, give support to the civil rights bill, which we have been asking at your hands, lo! these many days." 185 "I regret very much to say," he added, "that whenever a bill comes up here which is designed to relieve and benefit the outraged and oppressed negro population of this country ... [the Democrats'] apparent eagerness to defeat such desirable measures is perceptible on every hand, and is known to all." ${ }^{186}$ But no civil rights bill was enacted in 1872 .

\section{A FourteEnTH AMENDMENT ElegY}

Let us now pause to contemplate the wider implications of amnesty. One observation is that Congress was expressing a growing pessimism among Northern whites with Reconstruction. To some extent, that feeling was reflected outside of the Capitol by the Liberal Republican faction, with its message-through Section Three relief - of letting bygones be bygones in the white South. Within Congress, there was also a sense that vigorous enforcement of Section Three was accomplishing nothing. This frustration reached its conclusion in the "Compromise of 1877," when Union troops were withdrawn from the ex-Confederacy and real federal enforcement of the Fourteenth Amendment on matters of race ended. ${ }^{187}$ The Compromise of 1877 can be described as amnesty writ large for southern whites at the expense of the freed slaves. In other words, Section Three amnesty was a sign of grim things to come. ${ }^{188}$

184. Id. at 3382-83 (statement of Rep. Rainey)

185. Id. at 3383 (statement of Rep. Rainey).

186. Id. (statement of Rep. Rainey); see 2 BlaINE, supra note 3, at 515 ("[I]t must always be mentioned to the credit of the colored man that he gave his vote for amnesty to his former master when his demand for delay would have obstructed the passage of the measure."); see also CONG. GLOBE, 42d Cong., 2d Sess. 3383 (1872) (statement of Rep. Rainey) (stating that Republicans did not "want of the knowledge of parliamentary tactics by which legislation is often retarded"). When the Amnesty Act became law, the President ordered the dismissal of the quo warranto actions brought to enforce Section Three. See Ulysses S. Grant, Proclamation (June 1, 1872), in 9 MESSAGES, supra note 11, 4130, at 4130-31.

187. See CHERNOW, supra note 13 , at 849 .

188. I do not want to overstate the point. President Grant and a Republican Congress 
The second observation is that the Amnesty Act was part of a more general congressional retreat on the Fourteenth Amendment that preceded the Supreme Court's decision in Slaughter-House. In the midst of the amnesty debate on Section Three, Congress seriously considered for the first (and last) time if Section Two's representation penalty should be enforced. ${ }^{189}$ In spite of data from the 1870 Census indicating that both Rhode Island and Arkansas should lose one Representative and an electoral vote due to their suffrage limits, Congress decided to take no action. ${ }^{190}$ When combined with the near-simultaneous decision to grant amnesty, the not-so-subtle message was that broad constructions of the Fourteenth Amendment were out of favor. This was the backdrop for Slaughter-House, in which the Court took a narrow view of Section One in $1873 .{ }^{191}$ The Court gets pounded for that decision, but that criticism overlooks the fact that Slaughter-House was a lagging rather than a leading indicator for the Fourteenth Amendment given the decisions by Congress on Sections Two and Three a year before. The Justices often take their constitutional cues from the elected branches, and in Slaughter-House one could say that is exactly what they were doing.

Third, the amnesty debate was an early example of the gravitational pull of "returning to normal" in applying the

were reelected in 1872. See CHERNOW, supra note 13, at 751. The President took further steps to enforce the Fourteenth Amendment during his second term. See id. at 757-63, 788-95. And in 1875, a more modest version of Senator Sumner's civil rights measure was enacted (after Sumner's death) as the Civil Rights Act of 1875. See FONER, supra note 15, at 141-43. Nonetheless, the logic of amnesty prevailed after Grant left office.

189. See Magliocca, supra note 33, at 786-89.

190. See Act of Feb. 2, 1872, ch. 11, 17 Stat. 28 (1872); Magliocca, supra note 33, at 788-89. Rhode Island denied suffrage to men who had lived in the state for less than one year or owned less than $\$ 134$ of real property. See CONG. GLOBE, 42d Cong., 2d Sess. 82 (1871) (statement of Rep. Cox) (explaining this point). Arkansas denied voting rights to men who (1) had lived in the state for less than six months; (2) had fought in a dual; (3) were legally insane; or (4) were barred from voting in the state where they lived before they moved to Arkansas. See H.R. REP. NO. 41-3, at 72 (1870). In fairness to Congress, the census data on suffrage suffered from reliability issues. See CONG. GLOBE, 42d Cong., 2d Sess. 79 (1871) (quoting the Interior Secretary's view that he was "disposed to give but little credit to the returns made by assistant marshals in regard to the denial or abridgment of suffrage [under Section Two]"). But another issue was that Congress flinched from the political implications of applying Section Two to a Northern State and of inflaming white anger in Arkansas.

191. See Slaughter-House Cases, 83 U.S. (16 Wall.) 36 (1873); see also McDonald v. City of Chicago, 561 U.S. 742, 756-57 (2010) (acknowledging the scholarly criticism of Slaughter-House). 
Fourteenth Amendment on matters of race. In part, this urge may simply reflect an understanding that the text should be read as an anti-classification principle rather than in anti-subordination terms. But one can also say that the anti-subordination view is sustainable, but only for a limited time. This was a rationale given by the Court in The Civil Rights Cases and in Grutter v. Bollinger in explaining what were seen as controversial readings of Section One. ${ }^{192}$ Some members of Congress took a similar view in saying that the tension between Section Three and Section One was intolerable (with a few exceptions) four years after the Fourteenth Amendment's ratification. Of course, in that context the baseline (as the Black Representatives pointed out) left out significant federal protections for the freed slaves. ${ }^{193}$

Finally, the amnesty discussion encapsulated a basic dilemma that followed the American Civil War and that follows any civil war: What is the best way to reunite a divided nation? Is the answer "malice towards none, [and] charity for all," which implies broad and rapid forgiveness? ${ }^{194} \mathrm{Or}$ is the answer to take stern measures against the losers, as John Bingham claimed when he said in 1866 that "unless you put [the South] in terror of the power of your laws, made efficient by the solemn act of the whole people to punish the violators of oaths, they may defy your restricted legislative power when reconstructed." ${ }^{195}$ The tragic answer may be that neither is right or that both are not enough. Section Three embodied both approaches by providing for exclusions from office and for clemency, but by 1872 few were satisfied with this part of the Fourteenth Amendment.

192. See The Civil Rights Cases, 109 U.S. 3, 25 (1883) ("When a man has emerged from slavery, and by the aid of beneficent legislation has shaken off the inseparable concomitants of that state, there must be some stage in the progress of his elevation when he takes the rank of a mere citizen, and ceases to be the special favorite of the laws, and when his rights as a citizen, or a man, are to be protected in the ordinary modes by which other men's rights are protected."); Grutter v. Bollinger, 539 U.S. 306, 343 (2003) ("We expect that 25 years from now, the use of racial preferences will no longer be necessary to further the interest approved today.").

193. One could add, parenthetically, that Griffin's Case when paired with Davis also expressed a view about hewing to tradition in a manner that worked to the advantage of whites and the disadvantage of Blacks. See supra text accompanying notes 109-110.

194. See Abraham Lincoln, Second Inaugural Address (Mar. 4, 1865), in 8 MESSAGES, supra note 11 , at 3477,3478 .

195. Cong. Globe, 39th Cong., 1st Sess. 1094 (1866) (statement of Rep. Bingham). 


\section{PART IV. FORGETFULNESS}

This Part investigates Section Three's ironic disappearance from constitutional law. After the Amnesty Act of 1872, President Grant called on Congress to remove the disabilities from those who remained excluded from office. ${ }^{196}$ This action did not occur until 1898, but, in the meantime, Section Three was given a revisionist interpretation by the first Democratic Attorney General to serve after the Civil War. ${ }^{197}$ Much later came the final twist of history, which was that the final man to receive Section Three relief was the first man who claimed its protectionJefferson Davis.

\section{A. ATTORNEY GENERAL GARLAND's OPINION}

In 1885, Augustus Garland became President Cleveland's first Attorney General. ${ }^{198}$ Garland was a well-regarded lawyer who served in the Confederate Congress. ${ }^{199}$ Like most white Southerners, he received a pardon from President Andrew Johnson, but was not permitted to practice law in the Supreme Court under an Act of Congress providing that anyone who served in the Confederacy was, in effect, ineligible. ${ }^{200}$ Garland filed a brief on his own behalf and persuaded a bare majority of the Court in Ex parte Garland that the Act of Congress was unconstitutional for practice as applied to a recipient of a presidential pardon. ${ }^{201}$

Nineteen years later, Attorney General Garland issued a Section Three opinion that drastically limited the scope of that provision. The case involved Alexander R. Lawton, a United

196. Ulysses S. Grant, Fifth Annual Message (Dec. 1, 1873), in 10 MessAGES, supra note 11, at 4189, 4209 ("I renew my previous recommendation to Congress for general amnesty. The number engaged in the late rebellion yet laboring under disabilities is very small, but enough to keep up a constant irritation. No possible danger can accrue to the Government by restoring them to eligibility to hold office.").

197. See Lawton's Case, 18 Op. Att'y Gen 149-53 (1885) [hereinafter Lawton's Case]; EDMUND MORRIS, THE RISE OF THEOdORE ROOSEVElT 291 (1979) (noting Grover Cleveland's election in 1884 as the first Democratic President for a quarter-century).

198. See, e.g., Zachary Newkirk, Gray Jackets and Rifles to Black Robes and Gavels: Confederate Veterans in the U.S. Federal Courts from Ulysses S. Grant to William H. Taft, 22 J.S. LEGAL HIST. 187, 201 (2014).

199. See Ex parte Garland, 71 U.S. (4 Wall.) 333, 375 (1866). Garland was pending in the Supreme Court when Section Three was discussed in Congress and that case was mentioned in that discussion. See BLAINE, supra note 3, at 209.

200. See Ex parte Garland, 71 U.S. at 375.

201. See id. at 338, 381; id. at 382-99 (Miller, J., dissenting). Three other Justices joined Justice Miller's dissent. See id. at 382. 
States Army officer who served in the Confederate Army. ${ }^{202}$ United States Military officers were excluded from the 1872 amnesty, but Garland ruled that Section Three did not apply to officers who received a presidential pardon. ${ }^{203}$ In part, he said that this was because pardons restored the grantees "to all their rights as citizens" and made them "as innocent as if they had never committed the offenses forgiven." 204 The principal case that the Attorney General cited for that proposition was Ex parte Garland, which he must have done with a wink. ${ }^{205}$ Garland then said that Section Three must "be restricted if necessary to prevent an unjust and absurd consequence, which it must be presumed the legislature could not have contemplated." ${ }^{206}$ For that point, the Attorney General cited Slaughter-House, "where the court refused to adopt the full meaning of certain general words in the first section of the fourteenth amendment in order to avoid an interpretation that would have involved 'so great a departure from the structure and spirit of our institutions' as, in the absence of explicit language, could not be presumed to have been intended." ${ }^{207}$ Garland concluded that applying Section Three to someone with a pardon "would be productive of an injustice and a disregard of the public faith which nothing short of the most explicit and controlling language should authorize."208

The Attorney General's analysis was seriously flawed, though he did accurately capture the Zeitgeist of Section Three in 1885. First, the Senate did consider and expressly rejected language in Section Three that would have made an exception for those who received presidential pardons. ${ }^{209}$ Second, the Amnesty Act of 1872 made little sense if Section Three did not apply to men

202. See Lawton's Case, 18 Op. Att'y Gen., supra note 197, at 149. Lawton was the President of the American Bar Association and (after Garland's opinion was issued) was appointed as Minister to the Austro-Hungarian Empire. See WiLliam W. FreEhling, 2 THE ROAD TO DISUNION: SECESSIONISTS TRIUMPHANT, 1854-1861, at 482 (2007).

203. See Act of May 22, 1872, ch. 193, 17 Stat. 142; Lawton's Case, 18 Op. Att'y Gen., at $151-52$.

204. Lawton's Case, 18 Op. Att'y Gen., at 150; see id. at 152.

205. See id. at 150 .

206. Id. at 150-51; see id. at 152 (refusing to impute "to the framers of the third section of the [fourteenth] amendment either ignorance of the law or the purpose to set a snare to say that they intended to include persons already pardoned without specially referring to them").

207. Id. at 151 .

208. Id. at 152; see id. (stating that otherwise Lawton would "have been degraded by the amendment to the condition of disability from which their pardons had raised them").

209. See supra note 37 . 
who were pardoned. Andrew Johnson pardoned almost everyone in the Confederacy, including those covered by the Act's exceptions. ${ }^{210}$ Thus, under Attorney General Garland's theory there was no need for Congress to agonize over amnesty because Section Three applied to at best a few people. Needless to say, this was not the view in Congress when the Act was under consideration. ${ }^{211}$ Still, the Attorney General was correct in the sense that nobody cared about enforcing Section Three by 1885 , and so President Johnson's pardons might as well be treated as controlling.

\section{B. THE AMNESTY ACT OF 1898}

The outbreak of the Spanish-American War created the strongest nationalist sentiment in the United States since the Civil War. In the wake of that patriotic fervor, legislation was introduced in Congress to remove formally the remaining Section Three disabilities. ${ }^{212}$ By that point, there were only a few hundred living ex-Confederates who were excluded by the 1872 Act, but further amnesty carried symbolic weight. ${ }^{213}$ As the House Judiciary Committee Report supporting the legislation explained: "What a glorious spectacle in so short a time - the North and South, once so fiercely divided, reunited. The North willing to remove all political disabilities, wipe out all sectional feelings, and the South ready to defend the nation with their lives and their money." 214

The discussion of this amnesty was briefer than what occurred in 1872, but there were echoes of the earlier debate. One was that granting Section Three amnesty was an egalitarian act. A Representative said that the bill meant "all discriminations made necessary in the reconstruction period after the war shall now be removed, and that the equality of all men declared by the Declaration of Independence shall be restored under the flag of

210. See, e.g., Andrew Johnson, Proclamation (May 29, 1865), in 8 MESSAGES, supra note 11 , at $3508,3508-10$,

211. In other words, nobody in Congress in 1871 or 1872 said that Section Three relief was unnecessary because of President Johnson's pardons.

212. Act of June 6,1898 , ch. 389,30 Stat. 432. I say formally because under Attorney General Garland's interpretation in 1885 virtually no disabilities remained.

213. Cf. BLAINE, supra note 3, at 513 (stating that no more than 750 men were excluded from the 1872 amnesty, which meant that fewer were alive to take advantage of the 1898 amnesty).

214. 31 CONG. REC. 5405 (1898) (quoting the House Judiciary Committee Report). 
the Union." ${ }^{215}$ Notably absent from the equality rhetoric was any discussion of civil rights for Blacks. The House Judiciary Committee Report quoted at length from James G. Blaine's account of Section Three that this Article uses as a source, but all of Blaine's references to civil rights or to Representative Rainey's 1872 speech were scrubbed. ${ }^{216}$ Congress's general amnesty in 1898 ended the debate on the application of Section Three to exConfederates until the 1970 s.

\section{ROBERT E. LEE AND JEFFERSON DAVIS}

The surprising postscript to Section Three began in 1975, when Congress decided to grant a posthumous disability removal to Robert E. Lee. ${ }^{217}$ Lee died in 1870 and thus was not covered by the 1872 amnesty. ${ }^{218}$ The initial idea was that Lee's clemency would be combined with amnesty for Vietnam War draft evaders, but - as in 1872-Congress concluded that Lee's Section Three relief should be freestanding. ${ }^{219}$ The ensuing Joint Resolution stated, in part: "[T]his entire Nation has long recognized the outstanding virtues of courage, patriotism, and selfless devotion to duty of General R. E. Lee, and has recognized the contribution of General Lee in healing the wounds of the War Between the States ...."220 President Gerald Ford signed the Joint Resolution, stating that "General Lee's character has been an example to succeeding generations, making the restoration of his citizenship an event in which every American can take pride." 221 Whether

215. See id. at 5410 (statement of Rep. Parker).

216. Compare id. at 5404-05 (quoting selectively from Blaine's Twenty Years of Congress), with BLAINE, supra note 3, at 513-15 (providing the original passage).

217. S.J. Res. 23, 94th Cong. (1975). A common mischaracterization of this joint resolution is that Congress restored Lee's citizenship. See Marjorie Hunter, Citizenship Is Voted For Robert E. Lee, N.Y. TIMES, July 23, 1975, at 1 . Section Three did not strip anyone of citizenship, though the provision did remove a right of citizenship.

218. S.J. Res. 23, 94th Cong. (1975) (noting Lee's death on October 12, 1870); see Francis MacDonnell, Reconstruction in the Wake of Vietnam: The Pardoning of Robert E. Lee and Jefferson Davis, 40 CIV. WAR HIST. 119, 125-26 (1994).

219. See Richard D. Lyons, Amnesty Amendment May Be Attached to Resolution Restoring Lee's Citizenship, N.Y. TIMES, May 12,1974, at 41; see also Hunter, supra note 217, at 1 (stating that a few Representatives voted against Lee's amnesty because Vietnam War draft evaders were not included).

220. S.J. Res. 23, 94th Cong. (1975); see id. ("[I]n accordance with section 3 of amendment 14 of the United States Constitution, the legal disabilities placed upon General Lee as a result of his service as General of the Army of Northern Virginia are removed ....").

221. Gerald R. Ford, Remarks Upon Signing a Bill Restoring Rights of Citizenship to General Robert E. Lee, in 2 Pub. PAPERS 1111, 1112 (Aug. 5, 1975). President Ford 
Blacks were proud of this restoration was not discussed, but media reports suggested that Ford was more interested in shoring up his support among white Southerners in advance of the 1976 presidential election. ${ }^{222}$

Three years later, Jefferson Davis received Section Three relief. ${ }^{223}$ Davis died in 1889 and was, of course, not included in the 1872 amnesty. ${ }^{224}$ In introducing the Joint Resolution giving Davis his disability removal, Senator Mark Hatfield quoted Chief Justice Chase's declaration that "[w]e cannot convict [Davis] of treason," though he seemed unaware that Chase used Section Three to make that argument. ${ }^{225}$ President Carter signed that Joint Resolution and explained that "Congress officially completes the long process of reconciliation that has reunited our people following the tragic conflict between the States."226 "Our Nation," Carter stated, "needs to clear away the guilts and enmities and recriminations of the past, to finally set at rest the divisions that threatened to destroy our Nation and to discredit the great principles on which it was founded." 227 Post-Vietnam divisions were part of the subtext of the President's remarks, as he had given broad clemency to that war's draft evaders in $1977 .^{228}$

A through line connects the Section Three relief granted in the 1870s and in the 1970s. First, in both cases Congress stressed moving on from the past rather than confronting a troubled legacy. Second, immediate political considerations played a significant role in the decisions to award amnesty. Third, there

delivered this statement at Arlington House, Robert E. Lee's home that is now part of Arlington National Cemetery.

222. See MacDonnell, supra note 218, at 128 (quoting a report on the CBS Evening News with Walter Cronkite).

223. S.J. Res. 16, 95th Cong. (1978) ("[I]n accordance with section 3 of amendment XIV of the Constitution of the United States, the legal disabilities placed upon Mr. Jefferson F. Davis are hereby removed ...."). Unlike the Lee resolution, Davis's did not make any references to his character.

224. See WARREN, supra note 6, at 93.

225. See id. at 94 .

226. Jimmy Carter, Restoration of Citizenship Rights to Jefferson F. Davis, 2 PUB. PAPERS 1786, 1786 (Oct. 17, 1978).

227. Id.

228. See MacDonnell, supra note 218, at 129-30; cf. Jimmy Carter, Remarks and a Question-and-Answer Session With Department Employees, 1 PUB. PAPERS 259, 266 (Mar. 1, 1977) (defending his clemency order for draft evaders and stating: "I have also a historical perspective about this question. I come from the South. I know at the end of the War Between the States there was a sense of forgiveness for those who had been not loyal to our country in the past...."). 
was an undeniable white perspective to these questions, with scant attention given to Black perspectives on the Civil War. For example, Senator Hatfield used the hoary line that Jefferson Davis was the victim of "a vindictive conqueror" and that Section Three relief would right "a grave injustice." ${ }^{229}$ Likewise, another Senator repurposed Robert E. Lee as a bold dissenter and that "we revere him because he had the guts to say no when he thought his country was wrong." ${ }^{230}$ But wrong about what?

Accordingly, the purpose of Section Three was erased from the Constitution less than a generation after ratification. This was part of a broader trend in which the Fourteenth Amendment was cut loose from its moorings and set onto a much different course in the Gilded Age. Unlike other aspects of the Fourteenth Amendment, though, Section Three never recovered its rightful place in the twentieth century.

\section{CONCLUSION}

The Constitution is probably the most closely read secular document in the world, but there are still some unexplored parts in the text. Section Three of the Fourteenth Amendment is one of those ignored provisions that teaches some important lessons about law and politics, even though those are lessons of failure. ${ }^{231}$ The history of Section Three provides a more holistic view of the Fourteenth Amendment and shines a spotlight on how Congress's crucial role in shaping the meaning of the text in the ratification process and through amnesty, before Slaughter-House. Focusing on Section Three brings Chief Justice Chase's heretofore obscure opinion in Griffin's Case into the foreground as a template for Fourteenth Amendment judicial decisions down to the present day. Finally, the amnesty debate in Congress contains some profound observations from the first Blacks in the House of Representatives that are otherwise typically absent from the discussion of the Fourteenth Amendment's construction.

On the question of how to mend divided societies, Section Three is a cautionary tale. Targeting public officials may not be enough, as President Grant noted when he said, in advocating

229. 123 CONG. REC. 2075 (1977) (statement of Sen. Hatfield).

230. 121 CONG. REC. 9879 (1975) (statement of Sen. Hart).

231. Other aspects of my scholarship take an interest in constitutional failures, such as Prohibition or William Jennings Bryan's unsuccessful presidential election campaign in 1896 and the impact of that defeat on constitutional doctrine. Failure is illuminating. 
amnesty, that in free and fair votes "majorities are sure to elect officers reflecting the views of the majority." ${ }^{232}$ On the other hand, sweeping Section Three relief did not fulfill the goal of Reconstruction, by inducing reciprocal magnanimity to the freed slaves. In the end, neither the clenched fist nor the open hand brought justice for all.

232. Ulysses S. Grant, Third Annual Message (Dec. 4, 1871), in 9 MessagES, supra note 11 , at 4096, 4107. 